\title{
Model examination of chemoprevention with retinoids in squamous cell carcinomas of the head and neck region and suitable biomarkers for chemoprevention
}

\author{
EVA-MARIA FABRICIUS ${ }^{1}$, UTE KRUSE-BOITSCHENKO ${ }^{1}$, ULRICH SCHNEEWEISS ${ }^{2}$, \\ GUSTAV-PAUL WILDNER $^{2}$, BODO HOFFMEISTER ${ }^{1}$ and JAN-DIRK RAGUSE $^{1}$ \\ ${ }^{1}$ Clinic for Oral and Maxillofacial Surgery, Campus Virchow Hospital and \\ ${ }^{2}$ Robert-Rössle-Clinic, Campus Berlin-Buch, Charité - Universitätsmedizin Berlin, Germany
}

Received April 14, 2011; Accepted May 9, 2011

DOI: 10.3892/ijo.2011.1139

\begin{abstract}
The prognosis for patients with head and neck tumors (HNSCC) is poor, due among other things to the high-risk factor for locoregional recurrence and/or second primary tumors. Extensive studies on chemoprevention of oral pre-cancers to stop carcinogenesis and to prevent recurrence and/or second primary tumors have failed to reach the desired effects. The toxicity of retinoids (RA) for example limits their dosage. Biomarkers are used to evaluate the duration of therapy. In this study, cell culture models are used to demonstrate immunocytochemical expression of RA receptors (RAR, RXR), Ki-67 and p53 before and after all-trans retinoic acid (ATRA) treatment. Telomerase activity in PCR is used to assess the effectiveness of ATRA. Along with an RA-sensitive HNSCC cell line UM-SCC-35 we employed cell lines UM-SCC-14C and $\mathrm{HaCaT}$. Our immunocytochemical examination produced no proof of a statistically significant change in expression of RAR $\alpha, \operatorname{RAR} \beta$ or $\operatorname{RXR} \gamma$ receptors after ATRA treatment,
\end{abstract}

Correspondence to: Dr Eva-Maria Fabricius, Charité - Universitätsmedizin, Campus Virchow Hospital, Clinic for Oral and Maxillofacial Surgery, Augustenburger Platz 1, D-13353 Berlin, Germany

E-mail: eva-maria.fabricius@charite.de

Abbreviations: Ab, antibody; ATRA, all-trans retinoic acid; DMSO, dimethyl sulfoxide; HaCaT, human adult low calcium high temperature keratinocytes; HNSCC, head and neck squamous cell carcinoma; hTERT, human telomerase reverse transcriptase; IRS, immunoreactive scores; mRNA, messenger ribonucleic acid; mtp53, mutant form of p53; MTT, methyl thiazolyl tetrazolium; PCR, polymerase chain reaction; RA, retinoic acid; 9-cRA, 9-cis-RA, 9-cis retinoic acid; 13-cRA, 13-cis-RA, 13-cis retinoic acid; RAR, retinoic acid receptors; $\mathrm{RXR}$, retinoid $\mathrm{X}$ receptors; UM-SCC; University of Michigan-squamous cell carcinoma; wtp53, wild-type p53; XTT, a tetrazolium salt sodium 3'-[1-(phenylaminocarbonyl)3,4-tetrazolium]-bis (4-methoxy-6-nitro) benzene sulfonic acid hydrate

Key words: chemoprevention, biomarker, ATRA, RAR, RXR, UM-SCC-35, UM-SCC-14C, HaCaT, cytospins, head and neck squamous cell carcinoma, frozen sections, immunocytochemistry, immunohistochemistry, APAAP, Ki-67, p53, telomerase, XTT, MTT either in the cells of the sensitive UM-SCC-35 line or in HaCaT cells. The RAR $\beta$ and $\operatorname{RXR} \gamma$ receptors showed increased expression after brief cell treatment of UM-SCC-14C. The reduced telomerase activity after prolonged treatment of the UM-SCC-35-cells with ATRA (as well as the reduced p53 expression) proved to be a biomarker for evaluating the success of therapy. Although XTT and MTT tests demonstrated that cell proliferation in UM-SCC-35 cells was inhibited after brief and extended RA influence, the immunocytological Ki-67 scores failed to confirm the inhibition. No reduction of $\mathrm{p} 53$ expression, of telomerase activity or of cell proliferation in the XTT and MTT test was detected in the RA-insensitive cell line UM-SCC-14C or in HaCaT cells. We also demonstrated the parameters used in examining the models in sections of carcinoma tissue and in control tissues from the head and neck region, so they can be examined in clinical chemopreventive studies on biopsy tissue.

\section{Introduction}

Field cancerization (1) in the direct vicinity of the tumor of squamous cell carcinoma in the head and neck region (HNSCC) (2-4) and even a minimal residual tumor disease in the tumor margin (5-8) lead to locoregional recurrence and second primary tumors. In numerous studies researchers have been trying for years to influence carcinogenesis and postoperative outcome of disease (second field tumors, second primary tumors or minimal residual cancers) with chemoprevention (9-23). Patients with a field cancerization are potential target groups for the study of cancer prevention (22). The concept of chemoprevention was coined by Sporn et al in 1976 for the use of natural or synthetic chemical substances to prevent the occurrence of carcinomas or to inhibit or slow down the carcinogenetic process $(24,25)$.

For many years, natural or synthetic retinoids (26) have been the most common means for the chemoprevention of oral carcinomas in the head and neck region (9-14,17,18,27-31). They inhibit the cell proliferation of normal and malignant cells, modulate cell differentiation and trigger apoptosis (14-17,29,32$34)$. The cells are triggered in a G0/G1 cell cycle arrest thus prolonging the effectivity of the retinoids. This was demon- 
strated by Ran et al (33), Giannini et al (35), Hayashi et al (36), Masuda et al (37), Xiao et al (38) and Wang et al (39) on different HNSCC cell lines. According to Masuda et al (37) the portion of cells of the lines YCU-N861 (established from a nasopharynx carcinoma) and YXU-H891 (established from a hypopharynx carcinoma) increased after treatment with retinoids in the G1 phase from 63 to $86 \%$ and from 67 to $81 \%$. After treatment with retinoids the doubling time of HNSCC cell lines is prolonged, as Giannini et al (35) established in 7 further HNSCC cell lines (FADU, Hep-2, CCL, SCC-9, SCC-15, SCC 25 and HN-212).

In clinical studies the effectivity of chemoprevention was compared to placebo in the treatment of oral leukoplakia or in postoperative reduction of a second primary tumor in the head and neck region $(9,10,13-19,27-31,40,41)$. In some studies chemoprevention was started with an initially higher dose and the therapy was continued with a lower less toxic dose $(15,16,27,31,42-44)$. Results of the studies were contradictory and effectivity was not confirmed with a large enough number of patients $(11,14,30,40,42,44-48)$. The effect was often temporary (49) and waned markedly after the chemoprevention had been discontinued $(16,44)$. In already existent carcinomas or in metastases, Bolla et al (11) and Sun and Lotan (50) among others were unable to demonstrate an effect. Other factors such as not smoking or having stopped smoking or reduced alcohol consumption can also be significant for the outcome of oral carcinomas $(11,41,42,51-53)$. For this reason no binding recommendations have been made for chemoprophylaxis of head and neck tumors.

Some human oral squamous cell carcinoma cell lines were demonstrated to have a certain resistance to retinoids when their growth is only minimally or not at all inhibited $(28,36,37,54$ 56). This resistance could explain why chemoprevention has no effect in some studies. The effectivity of retinoids depends on the dosage. The toxicity of higher retinoid doses constitutes a restriction on its effectiveness and cannot be used for patients with preneoplasias (46). Khuri et al (43) however established no reduction of the second primary tumor in an extensive placebo-controlled phase III study on 1190 patients with low doses of isotretinoin (13-cis-RA), and Toma et al (30) found no effect of chemoprevention with lower doses of 13-cis-RA. Further clinical studies should be performed to test the use of a chemoprevention particularly on risk groups. To improve the effect of therapy and reduce the side-effects of chemoprevention efforts are being made to develop receptor-selective synthetic retinoids (14,28,50,57-65). According to Sun et al (61) synthetic retinoids are more effective and less toxic than natural retinoids.

The effects of retinoids are mediated by their nuclear receptors (retinoic acid receptors $\operatorname{RAR} \alpha, \operatorname{RAR} \beta, \operatorname{RAR} \gamma$ and retinoid $\mathrm{X}$ receptors $\mathrm{RXR} \alpha, \mathrm{RXR} \beta$ and $\mathrm{RXR} \gamma$ ). The activation and the affinity of the receptors are dependent on the particular retinoids being used: ATRA prefers a ligand for RAR receptors while 9-cis-RA prefers RXRs receptors but will also bind RAR receptors (66-73). The selectivity of the retinoids and rexinoids to particular receptors is probably also the explanation for their differing therapeutic effects. The discovery of the RA receptors in 1987 (66-69,74-76) was followed shortly by the development of synthetic retinoids, above all of synthetic receptor-selective retinoids $(70,71)$. In retinoic therapy, the growth and differen- tiation of cancer cells is modulated, presumably through the activation of gene transcription by nuclear RA receptors RAR and RXR (61). The expression of nuclear RA receptors RAR and RXR (74,77-83) has been demonstrated in several studies in oral leukoplakias and oral squamous cell carcinomas $(18,19,84-$ 93) with various methods. RAR $\beta$ expression is already downregulated when carcinogenesis begins in oral carcinomas and is often completely absent in them (19,47,50,88,89,93-95). Following successful retinoid treatment, RAR $\beta$ is again upregulated $(18,50,60,88-90)$. A failed treatment is reflected in lower or absent RAR $\beta$ upregulation $(50,88)$.

Long-range studies with different biomarkers were performed to determine the endpoint of a chemoprophylaxis $(60,96,97)$. The development of intermediate markers is crucial for chemoprevention trials (29). To determine a preliminary endpoint, genetic, cellular, biochemical or immunological surrogate biomarkers are being used and validated so that chemoprevention can be evaluated before a recurrence becomes evident. This requires an understanding of the biology of carcinogenesis to find biomarkers which reveal particular steps in tumor development (16,18,19,29,45,50,90,94,97-109). The demonstration of RAR $\beta$ (as an mRNA or as a protein in immunohistochemistry) was used in some studies as a sensitive biomarker for chemoprevention $(13,17,18,84,88,89,95)$.

The use of prognostic markers (e.g. p53, telomerase) is also helpful in developing chemopreventative strategies $(17,27,29$, $89,100,101,107,109,110)$. Geyer et al (17) found chemoprevention effective if the wild-type p53 had not yet mutated, and used p53 as a biomarker. Shin et al (89) used it as a biomarker for deciding whether to continue or discontinue a chemoprevention, and Niles recommends that it be validated in animal models (111).

In carcinoma-free tumor margin tissue from HNSCC, telomerase activation indicates the occurrence of field cancerization in this tissue and the first steps of carcinogenesis (110,112-117). Geyer et al (17), Hong et al (27), Lieberman et al (100), Koch (101), Kelloff et al (102) and Smith and Saba (107) recommended telomerase as a biomarker for assessing chemoprevention in tumors in the head and neck tumors region. Proof of telomerase as a biomarker for cancer incidence (102) has yet to be validated. Tsao et al (29) recommend e.g. using proof of hTERT, the catalytic subunit of telomerase. We have demonstrated hTERT in carcinoma-free adjacent tissues (118), whereby the immunohistochemical hTERT proof did not correlate in all cases with telomerase activity in the same tissue (PCR-ELISA).

In our model investigations of three cell lines we investigated whether proof of telomerase activity can be used as a biomarker for the effectiveness of chemoprevention. On the same model cells we compared the proliferation before and after retinoid therapy as well as the expression of several retinoid receptors, from Ki-67 and p53. We used the two HNSCC cell lines UM-SCC-14C and UM-SCC-35 $(119,120)$ and controlled with the spontaneously immortalized aneuploid human keratinocyte cell line HaCaT (121). The doubling time of UM-SCC-35 is between 38 (122) and $52 \mathrm{~h}$ (123), of UM-SCC-14 C it is $26 \mathrm{~h}$ $(119,120,123)$. HaCaT has a mean doubling time of $\sim 30 \mathrm{~h}(121)$. From the studies by Braakhuis et al (55), Copper et al (123) and Klaassen et al (124-126) we know that ATRA, depending on its dosage, inhibits the growth of cells of the line UM-SCC-35. 
Copper et al (123) and Klaassen et al (124), however, found that ATRA (124) and other retinoids (125) had no, or very little inhibiting effect on cells of the line UM-SCC-14C. Chen et al (127) investigated the restriction on growth of $\mathrm{HaCaT}$ exerted by various retinoids applied in increasing concentrations: Growth was inhibited strongest by increased concentration of retinoids, particularly by ATRA. Schroeder and Zouboulis (128) were also able to demonstrate dose-dependent inhibition of growth in HaCaT-cells, more clearly by 13 -cRA than by ATRA.

\section{Materials and methods}

Cell lines UM-SCC-35, UM-SCC-14C and HaCaT. Carey et al $(119,120)$ isolated the tumor cell lines from fresh head and neck cancer tissues: UM-SCC-35 for a primary tonsil carcinoma (T4N1M0, moderately well differentiated) and UM-SCC-14C for a skin metastasis of a floor and mouth carcinoma (poorly differentiated) after chemotherapy. The spontaneously immortalized aneuploid human keratinocyte cell line HaCaT was established by Boukamp et al (121) from the tumor-free skin area surrounding a melanoma. All cells were cultured in Dulbecco's modified Eagle's medium/NUT MIX F-12 (Gibco, Scotland, code 31 330-038), supplemented with $10 \%$ fetal calf serum (Biochrom KG, Berlin, Germany, code S 3113), $50 \mathrm{U} / \mathrm{ml}$ penicillin and $50 \mu \mathrm{g} / \mathrm{ml}$ streptomycin (Biochrom $\mathrm{KG}$, Berlin, Germany, code A 2213) and incubated at $37^{\circ} \mathrm{C}$ in a humidified atmosphere of $95 \%$ air and $5 \% \mathrm{CO}_{2}$. Following incubation of the cell lines with or without retinoid acid they were washed in medium three times. Cytological slide preparations for the immunocytochemical investigations were made with the help of a Shandon Centrifuge Cytospin3 (Life Science International $\mathrm{GmbH}$, USA; $850 \mathrm{RPM}, 5 \mathrm{~min}$ ) with single or double Cytofunnels. The preparations were then air-dried and stored ready for immunocytological dyeing at $-20^{\circ} \mathrm{C}$. Carcinoma tissue and control tissues were examined immunohistochemically. Cell proliferation before and after the effects of ATRA was also performed on the three cell lines UM-SCC35, UM-SCC-14C $(119,120)$ and HaCaT (121) in 96-well plates and the telomerase activity in all three cell lines before and after ATRA treatment was examined.

Chemicals. All-trans-RA (ATRA; Sigma-Aldrich, USA, code R-2625) was dissolved in the dark into dimethyl sulfoxide (DMSO; Merck KGaA, Darmstadt, Germany, code 109678) as a stock for $10^{-2} \mathrm{M}$ ATRA. Aliquots were stored at $-20^{\circ} \mathrm{C}$. For each experiment with $10^{-5} \mathrm{M}$ and/or $10^{-8} \mathrm{M}$ ATRA fresh working dilutions were prepared in the serum-free cell culture medium supplemented with $1 \mathrm{mg} / \mathrm{ml}$ bovine serum albumin (Sigma; code A-9647). With every change of medium $10 \mu \mathrm{l}$ ATRA was added to $10 \mathrm{ml}$ of the cell cultures, either $\sim 6$ days (short incubation) or 26 days (long incubation). DMSO (10 $\mu \mathrm{l})$ was added to the controls without RA. The final DMSO concentration was always $0.1 \%$ or lower and did not inhibit cell growth.

Immunocytochemical and immunohistochemical proof of the retinoid receptors $R A R$ and $R X R$ as well as of $K i-67$ and p53. Before beginning with the alkaline phosphatase anti-alkaline phosphatase (APAAP) technique (129), the cytospin prepara-

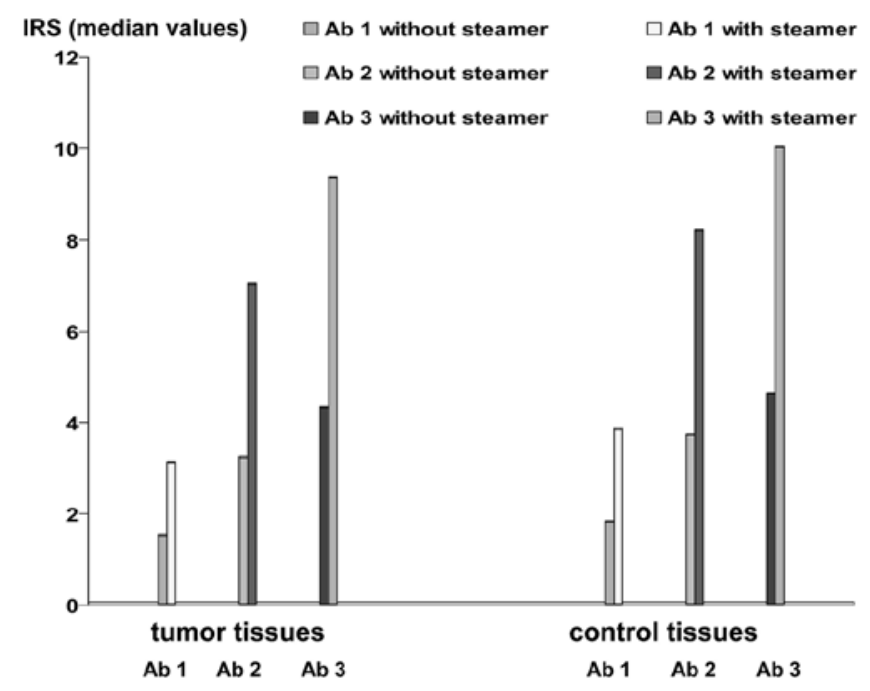

Figure 1. Preliminary experiment without and with pretreatment in the steamer. Ab 1, polyclonal rabbit anti-RAR $\alpha$-antibody sc-551; Ab 2, polyclonal rabbit anti-RAR $\beta$-antibody code ab15515; Ab 3, monoclonal mouse antiRXR $\alpha$-antibody clone 4E9.

tions that had been stored at -20 to $-80^{\circ} \mathrm{C}$ and the histological frozen sections were thawed slowly and fixed in methanol cooled at $-20^{\circ} \mathrm{C}$ for $10 \mathrm{~min}$ and acetone cooled at $-20^{\circ} \mathrm{C}$ for $1 \mathrm{~min}$. Before starting, we compared the immunohistochemical results on a few tissue sections without and with pretreatment in the steamer (Fig. 1). Steamer pretreatment proved the more effective method for nuclear presentation of receptors in frozen sections. The frozen sections and cytoslides were pretreated for $30 \mathrm{~min}$ in a Braun Multi Gourmet Plus FS20 steamer (Kronberg, Germany) in TRS (target retrieval solution)-Puffer S1699 (Dako Cytomation, Denmark) pH 6.1.

We applied the APAAP method (129) with the Universal Dako APAAP-kit (code K 670) as described by Fabricius et al (118), for immunohistochemical proof. Endogenous enzyme activity was inhibited by adding Levamisole hydrochloride (Sigma, code L-9756). Against RAR $\alpha$ the following antibodies were used with comparable results on histopathologic sections: the two monoclonal antibodies clone 763 (Cascade BioScience, USA) and clone H1920 (Abcam, USA) and one polyclonal antibody sc-551 (Santa Cruz Biotechnology Inc., USA). Against RAR $\beta$ we examined the monoclonal antibodies clone 336 (Cascade Bioscience) and clone SPM216 (Abcam) and the polyclonal antibody ab 15515 (Abcam), sc-552 (Santa Cruz Biotechnology Inc.) and NB 110-39045 (Novus Biologicals Inc., USA). Antibody ab15515 produced the clearest results. With sc-7387 (Santa Cruz Biotechnology Inc.), the only antibody available to us for RAR $\gamma$, all results were either negative or so minimal that we thereupon left it out of the study. Against $\mathrm{RXR} \alpha$ the results with the monoclonal antibody clone 4E9 (Novus Biologicals Inc.) were the same as those with the polyclonal sc-553 (Santa Cruz Biotechnology Inc.). For proof of RXR $\beta$ we used the polyclonal antibody sc-742 and sc-556 (both Santa Cruz Biotechnology Inc.). Antibody sc-742 rendered no coloring at all. For RXR $\beta$ we examined a monoclonal antibody clone 1373 (Cascade BioScience) and a polyclonal antibody sc-555 (Santa Cruz Biotechnology Inc.) 
Table I. Overview of primary antibodies used.

\begin{tabular}{|c|c|c|c|c|}
\hline Ab-code & Antibodies & Source; code & Characterization & Working dilution \\
\hline $\mathrm{Ab} 1$ & $\begin{array}{l}\text { Polyclonal rabbit anti- } \\
\text { RAR } \alpha \text {-antibody }(\mathrm{C}-20)\end{array}$ & $\begin{array}{l}\text { Santa Cruz Biotechnology, } \\
\text { Inc.; sc-551 }\end{array}$ & $\begin{array}{l}\text { Affinity purified IgG-antibody against } \\
\text { a peptide mapping at the C-terminus of } \\
\text { RAR } \alpha 1 \text { and } \operatorname{RAR} \alpha 2 \text { of human origin }\end{array}$ & $\begin{array}{c}1: 75 \\
\text { (cytospins 1:50) }\end{array}$ \\
\hline $\mathrm{Ab} 2$ & $\begin{array}{l}\text { Polyclonal rabbit } \\
\text { anti-RAR } \beta \text {-antibody }\end{array}$ & $\begin{array}{l}\text { Abcam (USA); } \\
\text { ab15515 }\end{array}$ & $\begin{array}{l}\text { Affinity purified IgG-antibody } \\
\text { against a synthetic peptide } \\
\text { (N-terminal) }\end{array}$ & $1: 15$ \\
\hline $\mathrm{Ab} 3$ & $\begin{array}{l}\text { Monoclonal mouse } \\
\text { anti-RXR } \alpha \text {-antibody } \\
\text { clone 4E9 }\end{array}$ & $\begin{array}{l}\text { Abnova (Novus } \\
\text { Biologicals, Inc.); } \\
\text { H00006256-M01 (NR2B1) }\end{array}$ & $\begin{array}{l}\text { Purified } \mathrm{IgG} 2 \mathrm{a}-\kappa \text { antibody against } \\
\text { partial recombinant RXRA }\end{array}$ & $1: 25$ \\
\hline $\mathrm{Ab} 4$ & $\begin{array}{l}\text { Polyclonal rabbit } \\
\text { anti-RXR } \beta_{1} \text {-antibody } \\
(\mathrm{L}-20)\end{array}$ & $\begin{array}{l}\text { Santa Cruz Biotechnology, } \\
\text { Inc.; sc-556 }\end{array}$ & $\begin{array}{l}\text { Affinity purified IgG-antibody raised } \\
\text { against a peptide mapping at the } \\
\text { N-terminus of RXR } \beta 1 \text { of mouse origin }\end{array}$ & $1: 20$ \\
\hline $\mathrm{Ab} 5$ & $\begin{array}{l}\text { Monoclonal mouse } \\
\text { anti-RXR } \gamma \text {-antibody } \\
\text { clone } 1373\end{array}$ & $\begin{array}{l}\text { Cascade Bioscience; } \\
\text { ABM-4821 }\end{array}$ & $\begin{array}{l}\text { Purified IgG2a- } \kappa \text { antibody against a } \\
\sim 60-\mathrm{kD} \text { a peptide derived from the hinge } \\
\text { region of human RXR- } \gamma \text {. Detects } \\
\mathrm{hRXR}-\gamma \text {; does not recognize } \alpha \\
\text { or } \beta \text { isotypes or hRAR. }\end{array}$ & $1: 10$ \\
\hline \multicolumn{5}{|c|}{ Positive control antibodies } \\
\hline $\mathrm{Ab} 6$ & $\begin{array}{l}\text { Monoclonal mouse } \\
\text { anti-Ki-67 antibody } \\
\text { clone MIB-1 }\end{array}$ & $\begin{array}{l}\text { Dako, Denmark } \\
\text { M7240 }\end{array}$ & $\begin{array}{l}\text { Immunogen human recombinant } \\
\text { peptide anti-human } \mathrm{Ki}-67 \mathrm{IgG} 1-\kappa \\
\text { antibody; corresponding to a } 1002-\mathrm{bp} \\
\mathrm{Ki}-67 \mathrm{cDNA}\end{array}$ & $1: 100$ \\
\hline $\mathrm{Ab} 7$ & $\begin{array}{l}\text { Monoclonal mouse anti- } \\
\text { mutated p53 antibody } \\
\text { Ab-3 (OP 29-1) } \\
\text { clone PAb240 }\end{array}$ & $\begin{array}{l}\text { Calbiochem (Oncogene), } \\
\text { USA; OP29 }\end{array}$ & $\begin{array}{l}\text { Purified IgG1-antibody against a } \\
\sim 53 \mathrm{kDa} \text { mutant p53 protein } \\
\text { under non-denaturing conditions, } \\
\text { recognizes both the mutant } \\
\text { and the wild-type p53 protein } \\
\text { under denaturing conditions }\end{array}$ & $1: 20$ \\
\hline
\end{tabular}

$\mathrm{Ab}$, antibody; RAR, retinoic acid receptors; $\mathrm{RXR}$, retinoid $\mathrm{X}$ receptors.

and obtained distinctly better results with the former. Table I lists the five antibodies $\mathrm{Ab} 1$ to $\mathrm{Ab} 5$ used for further experiments with cytospins and sections. We compared the results with a control using an antibody against Ki-67 (Ab 6) and an antibody against p53 (Ab 7). With some of the antibodies, only a limited number of tissues or cytoslides stained. The antibodies were diluted in S2022 (DakoCytomation, ready to use), incubated for $60 \mathrm{~min}$ at $37^{\circ} \mathrm{C}$ in the drying oven and then again for $30 \mathrm{~min}$ at room temperature.

To ensure the reliability of our immunohistochemical stainings we ran a parallel assay with a negative control for each staining (negative control sera mouse Dako code N1698, negative control sera rabbit Dako code N1699; ready for use). These control sera were negative. All incubation steps taken in the immunohistochemical staining process were performed in a humidified chamber. To block any non-specific reactions we incubated sections at room temperature for $20 \mathrm{~min}$ with the ready-made X0909 blocking buffer (DakoCytomation).

All score values given for anti-RAR/RXR-receptors, Ki-67 and p53 refer exclusively to nuclear stainings in culture cells, in the carcinoma tissues and in control epithelial tissues. Based on experience gained in our previous immunohistochemical studies with other antibodies (118) we used the immunohistochemical evaluation by Remmele et al (130). Evaluation of cytospins and tissue sections was performed three times at different time points by an independent examiner and was based on estimated values for staining intensity (SI: 0, no staining; $1+$, weak; $2+$, moderate; $3+$, strong and 4+, very strong staining) and percentage of positive staining in tissue sections (PP: 0, no positive cells; $1,1-25 \% ; 2,26-50 \% ; 3,51-75 \%$ and 4 , $76-100 \%$ positive cells). The immunohistochemical score value (IRS) was then calculated by multiplication of SI and PP. The evaluation was performed with a 40 -fold objective.

Tumor tissues and tissues without tumors with control tissue. All tissues examined were taken from the head and neck area with previous consent of the patients in our clinic in the context of diagnostics and therapy. The squamous cell carcinoma specimens were collected from 18 patients in the period from 1994 to 1997 (Table IIA). The entire frozen section series was examined 
Table II. Characterization of the patients with and without a head and neck squamous cell carcinoma (HNSCC) and localization of tissues.

A. Characterization of the 18 patients with a HNSCC.

\begin{tabular}{|c|c|c|c|c|c|}
\hline No. & Sex/age ${ }^{a}$ & Localization & $\mathrm{TNM}^{\mathrm{b}}$ & $S$ & $\mathrm{G}$ \\
\hline 1 & $\mathrm{M} / 39$ & Floor of mouth & pT3N1 & III & 3 \\
\hline 2 & $\mathrm{M} / 50$ & Floor of mouth & pT2N2b & IVA & 2 \\
\hline 3 & $\mathrm{M} / 50$ & Floor of mouth & pT4N1 & IVA & 2 \\
\hline 4 & $\mathrm{M} / 62$ & Floor of mouth & pT2N2 & IVA & 3 \\
\hline 5 & $\mathrm{M} / 50$ & Floor of mouth & pT4N1 & IVA & 3 \\
\hline 6 & $\mathrm{M} / 52$ & Floor of mouth & pT4N2c & IVB & 1 \\
\hline 7 & $\mathrm{M} / 60$ & Floor of mouth & pT4N1 & IVA & 3 \\
\hline 8 & $\mathrm{M} / 58$ & Floor of mouth/tongue & pT3N2 & IVA & 3 \\
\hline 9 & $\mathrm{M} / 57$ & Floor of mouth/tongue & pT4N0 & IVA & 2 \\
\hline 10 & $\mathrm{~F} / 65$ & Floor of mouth/tongue & pT2N0 & II & 2 \\
\hline 11 & $\mathrm{M} / 55$ & Tongue/floor of mouth & pT4N0 & IVA & 3 \\
\hline 12 & $\mathrm{~F} / 76$ & Buccal mucosa & pT3N1 & III & 2 \\
\hline 13 & $\mathrm{M} / 53$ & Alveolar process & pT4N2 & IVA & 2 \\
\hline 14 & $\mathrm{M} / 75$ & Lip & pT2N0 & II & 3 \\
\hline 15 & $\mathrm{M} / 57$ & Ear & pT4N1 & IVA & 3 \\
\hline 16 & $\mathrm{M} / 64$ & Ear & pT4N0 & IVA & 2 \\
\hline 17 & $\mathrm{M} / 68$ & Ear & pT4N0 & IVA & 2 \\
\hline 18 & $\mathrm{M} / 65$ & Ear & pT4N1 & IVA & 2 \\
\hline
\end{tabular}

B. Characterization of the 17 patients without tumor and localization of control tissues

\begin{tabular}{lll}
\hline 1 & $\mathrm{M} / 20$ & Gingiva \\
2 & $\mathrm{~F} / 56$ & Gingiva \\
3 & $\mathrm{~F} / 22$ & Gingiva \\
4 & $\mathrm{M} / 36$ & Oral mucosa \\
5 & $\mathrm{~F} / 36$ & Oral mucosa \\
6 & $\mathrm{~F} / 61$ & Oral mucosa \\
7 & $\mathrm{~F} / 64$ & Oral mucosa \\
8 & $\mathrm{~F} / 48$ & Buccal mucosa \\
9 & $\mathrm{M} / 61$ & Tongue \\
10 & $\mathrm{M} / 60$ & Tongue \\
11 & $\mathrm{M} / 46$ & Nose \\
12 & $\mathrm{M} / 30$ & Ear \\
13 & $\mathrm{~F} / 18$ & Ear \\
14 & $\mathrm{M} / 20$ & Chin \\
15 & $\mathrm{~F} / 55$ & Eyelid \\
16 & $\mathrm{M} / 55$ & Scalp \\
17 & $\mathrm{~F} / 10$ & Scalp \\
\hline
\end{tabular}

Sex: M, male; F, female; ${ }^{a}$ Age at tissue harvesting in years; ${ }^{\mathrm{b}} \mathrm{TNM}$-classification of malignant tumors (131); T, tumor; N, node; M, metastasis; S, staging; G, grading.

by a tumor pathologist (G.-P.W.) with conventional hemalauneosin staining to ensure that carcinoma was present in all tumor tissues. We examined tissue of different localizations from 16 males and 2 female patients aged $59 \pm 10$ years. Thirteen patients had oral and 5 extraoral squamous cell carcinomas. TNM classification (131) and degree of differentiation were established by the Institute of Pathology in our hospital. The immunohistochemical detection of RA-receptors as well as of Ki-67 and p53 was described previously. For a critical evaluation of RA-receptor expressions in carcinoma tissues we examined oral and extraoral control tissue from different localizations in 17 patients without tumor from our clinic in the period from 1994 


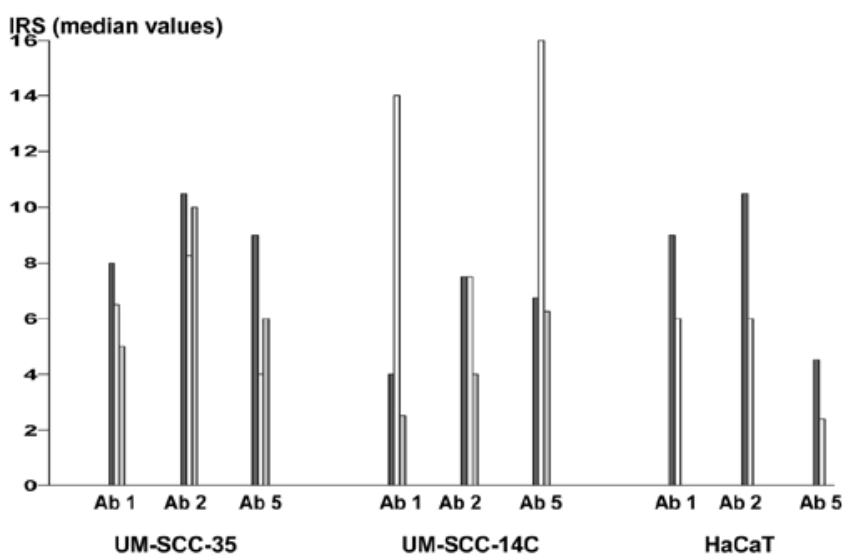

Figure 2. Expression of RA receptors on cells (antibodies in Table I): cultures without, after brief ( 6 days) and extended ( 26 days) treatment with $10^{-5} \mathrm{M}$ ATRA (UM-SCC-35 and UM-SCC-14C) and HaCaT, without and after brief treatment with $10^{-5} \mathrm{M}$ ATRA.

to 2004 (Table IIB), eight males and 9 females aged $41 \pm 18$ years. In the control tissue sections we also evaluated the RA-receptor expression of Ki-67 and p53 in squamous epithelium. We examined 10 oral and 7 extraoral tissues. The tissues were taken with the patients' consent in the context of therapy.

Examination of growth inhibition in XTT and MTT tests. To test the growth inhibition effect by $10^{-5} \mathrm{M}$ and $10^{-8} \mathrm{M}$ ATRA, we used two colorimetric assays for non-radioactive quantification of cell proliferation and viability, the Cell Proliferating Kit II, XTT-based (cat. no. 11465015 001) and for comparison in separate cell culture assays the Cell Proliferating Kit I, MTT-based (cat. no. 11465007 001) from Roche Diagnostics (Mannheim, Germany). From a larger volume we took $100 \mu \mathrm{l}$ cells in medium without phenol red with $\left(10^{-5}\right.$ and $10^{-8} \mathrm{M}$ ATRA) and without RA treatment, taking $2-5 \times 10^{3}$ cells/well of each, and deposited this on microplates (tissue culture grade, 96 wells, flat bottom). These were incubated for $24 \mathrm{~h}$ at $37^{\circ} \mathrm{C}$ and $5 \% \mathrm{CO}_{2}$. In the XTT test after adding $50 \mu \mathrm{l}$ of the XTT labelling mixture, we incubated the microplates once again for $24 \mathrm{~h}$ at $37^{\circ} \mathrm{C}$ and $5 \% \mathrm{CO}_{2}$, then took readings. In the MTT test, $10 \mu \mathrm{l}$ of the MTT labelling reagent was added and the cells were incubated $4 \mathrm{~h}$ at $37^{\circ} \mathrm{C}$ and $5 \% \mathrm{CO}_{2}$. Afterwards $100 \mu \mathrm{l}$ solubilization solution was added before the cells were again incubated overnight. To measure the spectrophotometrical absorbance of both tests we used a microplate reader (Dynatech MR 5000): XTT assay at a wavelength of $490 \mathrm{~nm}$ and a reference wave- length of $690 \mathrm{~nm}$ and MTT assay at a wavelength of $570 \mathrm{~nm}$ and reference wavelength of $690 \mathrm{~nm}$.

Determining telomerase activity in cell cultures before and after treatment with retinoids and in tissues. As described above (117), we used the test kits TeloTAGGG Telomerase PCR ELISA (Roche Diagnostics, Applied Science; cat. no. 11854666910) and TeloTAGGG Telomerase PCR ELISA ${ }^{\text {Plus }}$ (Roche Diagnostics, Applied Science, cat. no. 12013789001) to demonstrate telomerase activity. The frozen tissues from tumor and control patients (Table II) were lysed and the lysate adjusted with the addition of 0.5 and $5 \mu \mathrm{g}$ protein or, if necessary, amounts under $0.5 \mu \mathrm{g}$ per PCR trial. The cells were lysed

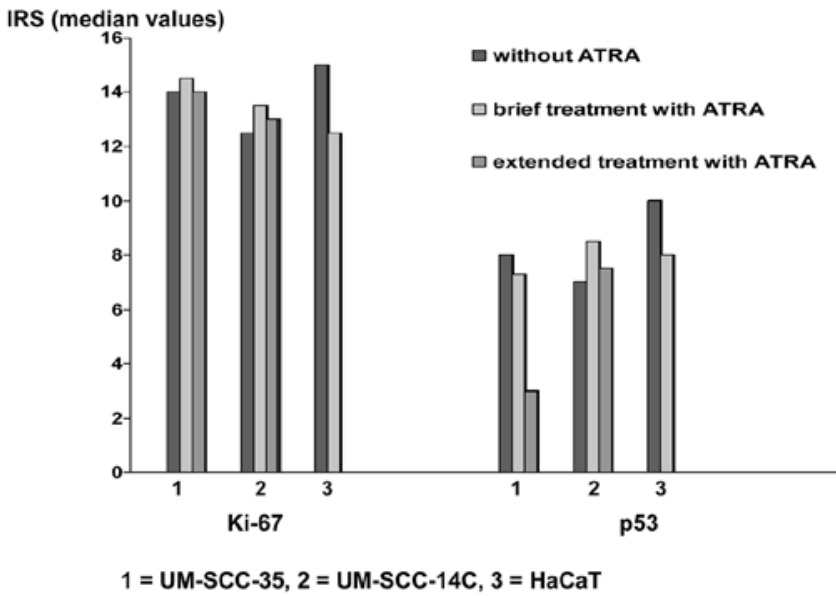

Figure 3. Expression of Ki-67 and p53 in the three cell lines before and after treatment with $10^{-5}$ M ATRA. UM-SCC-35 and UM-SCC-14C brief ( $~ 6$ days) and extended RA ( 26 days), HaCaT only brief RA.

before and after brief ( $\sim 6$ days) and extended ( 26 days) treatment with $10^{-5}$ ATRA; we used 0.005-0.1 (with retinoic acid to $0.5 \mu \mathrm{g}$ ) protein per PCR. Protein concentration in the cell lysates was determined in accordance with Lowry et al (132) using the Bio-Rad DC protein assay kit (Bio-Rad Laboratories, USA). With a subsequent ELISA it was then possible to detect telomerase activity in $\mathrm{mOD}$.

Statistical analysis. Statistical evaluation (133) was performed with PASW Statistics 18 Version 18.0.0. Apart from descriptive statistics, we compared median values using the Mann-Whitney $\mathrm{U}$ test or, if distribution was normal, we compared mean values using the t-test. Test results with $\mathrm{p} \leq 0.05$ were rated statistically significant.

\section{Results}

Immunocytological proof of $R A R$ and $R X R$ before and after brief and extended $R A$ treatment in cell cultures in comparison to $\mathrm{Ki}-67$ and $\mathrm{p} 53$. After the cytospins had been pretreated in the steamer (compare Fig. 1), we examined with different antibodies (Table I) the expression of the RAR and RXR receptors as well as of $\mathrm{Ki}-67$ and p53 on the cells in all three cell lines both before and after exposure to $10^{-5} \mathrm{M}$ and $10^{-8} \mathrm{M}$ ATRA. We ascertained median nuclear score values according to Remmele et al (130). With the one antibody against RAR $\gamma$ available to us (Santa Cruz Biotechnology Inc.; sc-7397) results were not evaluable in immunocytology or immunohistochemistry. We therefore abandoned its further use in this study. For repeated examinations for receptor expression in at least three separate cell culture assays we were constrained to use proof of $\operatorname{RAR} \alpha, \operatorname{RAR} \beta$ and RXR $\gamma$ with the antibodies Ab 1, Ab 2 and Ab 5 (Table I) for statistical assessment: Fig. 2 presents the median score values (130) before and after brief and extended treatment with $10^{-5} \mathrm{M}$ ATRA. We also demonstrated the receptors $\operatorname{RXR} \alpha(\mathrm{Ab} 3)$ and $\operatorname{RXR} \beta(\mathrm{Ab} 4)$ in the cell lines.

The score values for $\operatorname{RAR} \alpha, \operatorname{RAR} \beta$ and $\operatorname{RXR} \gamma$ in UM-SCC-35 cells were not significantly altered after ATRA treatment: without RA/brief RA Ab1: $p=0.667, \mathrm{Ab} 2: \mathrm{p}=0.667$, 
A1

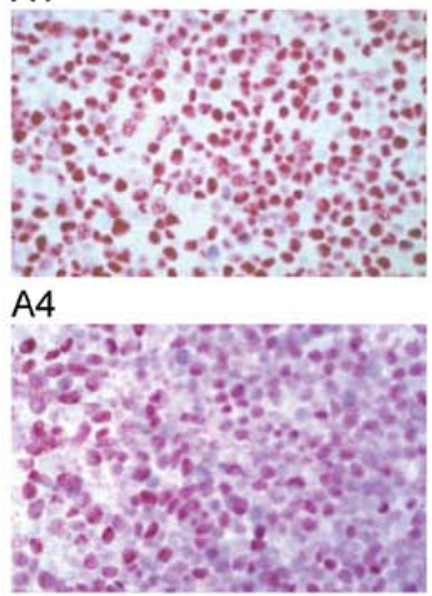

B1

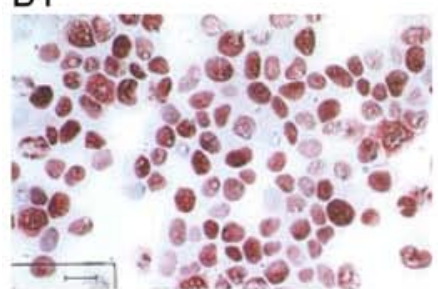

B4

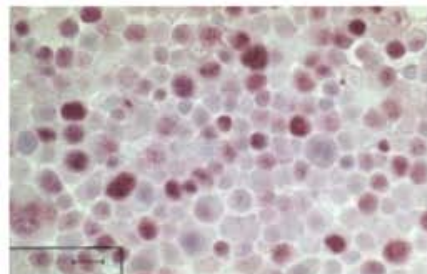

C1

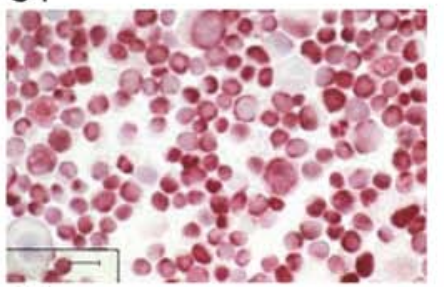

C4

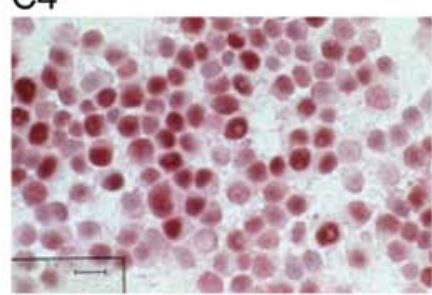

A2

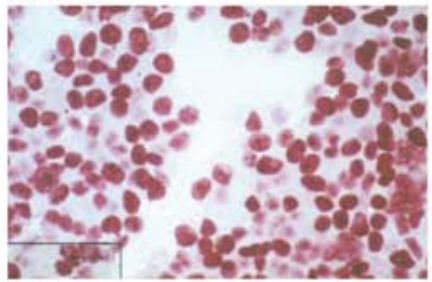

A5

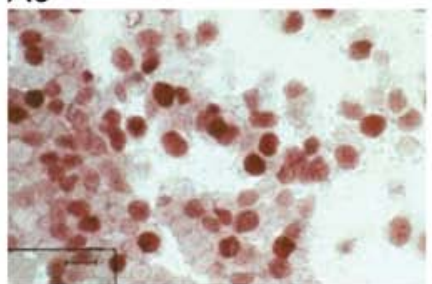

B2

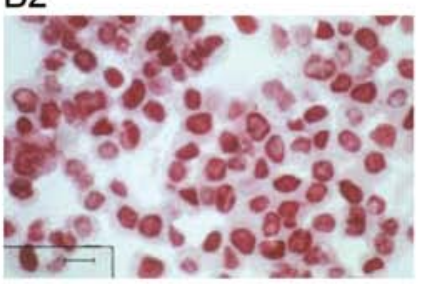

B5

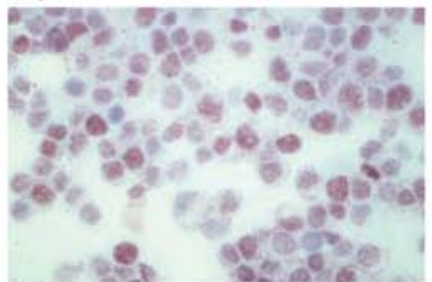

C2

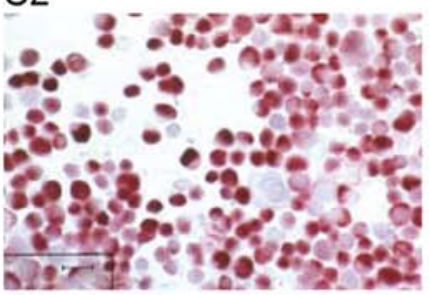

C5

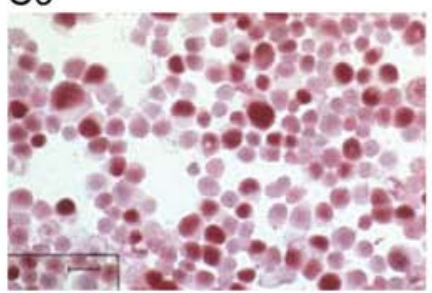

A3

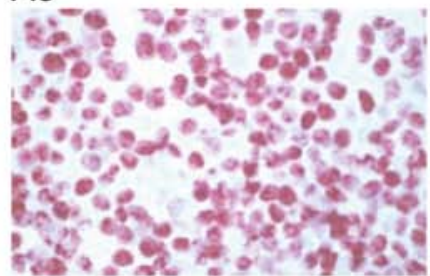

A6

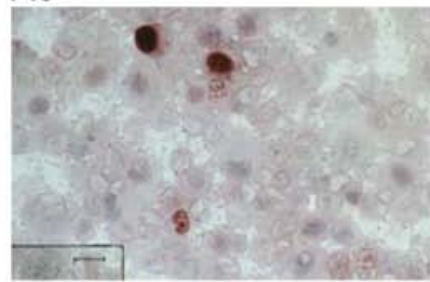

B3

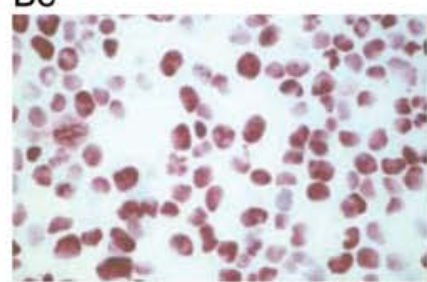

B6

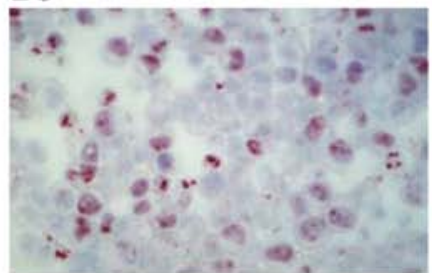

C3

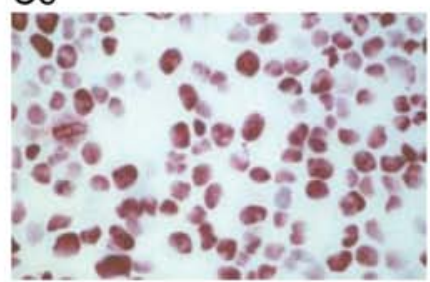

C6

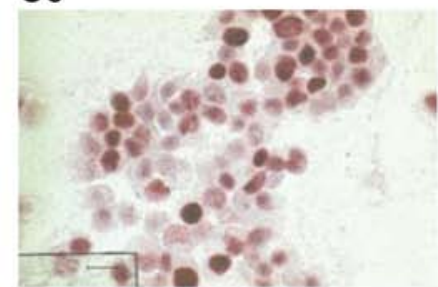

Figure 4. Expression of Ki-67 and p53 of the cells without and after brief treatment with ATRA. UM-SCC-35 (A1-A6), UM-SCC-14C (B1-B6) and HaCaT (C1C6). Without ATRA: A1, A4, B1, B4, C1, C4; after brief $10^{-8}$ M ATRA: A2, A5, B2, B5, C2, C5; after brief 10 5 M ATRA: A3, A6, B3, B6, C3, C6. Antibody 6 (anti-Ki-67) A1-A3, B1-B3, C1-C3; antibody 7 (anti-p53) A4-A6, B4-B6, C4-C6; bar, $20 \mu \mathrm{m}$.

Ab 5: $\mathrm{p}=0.333$; without RA/extended RA Ab 1 (Ab 2, Ab 5): $p=0.333$. The growth inhibiting effect of retinoid treatment on UM-SCC-35 cells which was demonstrated in the XTT and MTT assay (Fig. 7) was not reflected in the parameter Ki-67 (Figs. 3 and 4A1-A3): without RA/brief RA exposure ( $\sim 6$ days): Ki-67: $\mathrm{p}=0.963$; without RA/extended treatment with RA ( 26 days): Ki-67: $p=0.789$. By contrast, the expression of p53 was lower after extended RA treatment in the cells of UM-SCC-35 (Figs. 3 and 4A4-A6), with the reduction just reaching significance $(\mathrm{p}=0.058)$. Brief treatment with ATRA altered p53 expression only minimally: $\mathrm{p}=0.797$ (Fig. 3).

After brief treatment with RA, RAR $\alpha$ expression on the cells of UM-SCC-14C (Ab 1, Fig. 2) was significantly higher than on the untreated cells $(\mathrm{p}=0.019)$. This was not the case after extended RA treatment. In the same cells after only a brief treatment with RA, the expression of RXR $\gamma$ was distinctly 


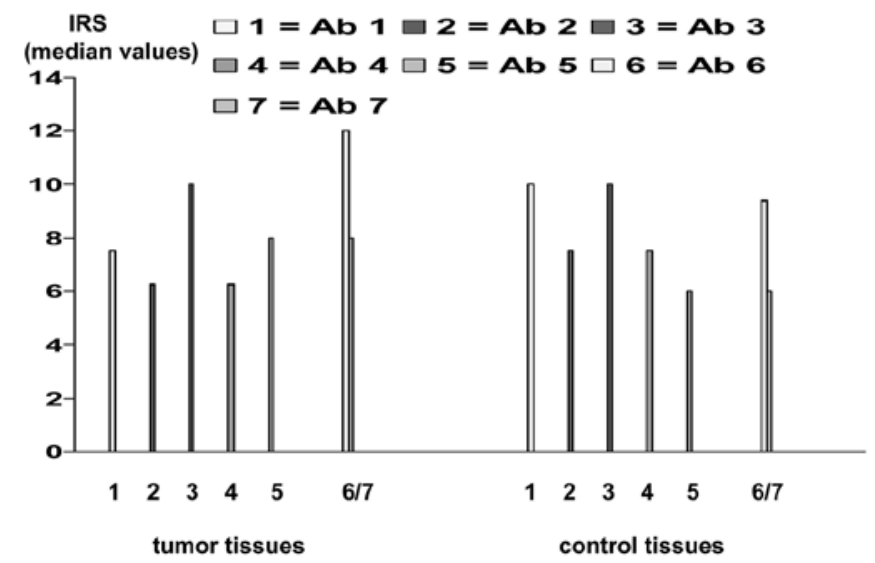

Figure 5. Expression of RA receptors and of Ki-67 and p53 in tissue sections (Tables I and II).

higher than on the untreated cells (Ab 5, p=0.062, Fig. 2), reaching borderline significance. The score values of the other parameters showed no significant differences: without RA/brief RA: Ab 2: p=1.000, Ki-67: p=0.919; without RA/ extended RA: Ab 1: $p=0.333, A b 2: p=0.667, A b$ 5: $p=1.000$; Ki-67: $\mathrm{p}=1.000$ (Fig. 4B1-B3), p53: $\mathrm{p}=0.724$ (Fig. 4B4-B6).

On the cells of the immortal keratinocyte cell line HaCaT, expression of the RA receptors after brief exposure with $10^{-5} \mathrm{M}$ ATRA did not significantly change (Fig. 2): Ab 1: $p=0.667$; $\mathrm{Ab}$ 2: $\mathrm{p}=0.333, \mathrm{Ab}$ 5: $\mathrm{p}=0.33$; nor were the parameters Ki-67 or p53 altered after brief RA treatment: Ki-67: $\mathrm{p}=0.200$, p53: p=0.974 (Figs. 3 and 4C1-C6).
Immunohistochemical proof of $R A R$ and $R X R$ receptors as well as of Ki-67 and p53 in tissue. We demonstrated all the parameters examined in the squamous cell carcinomas (Table IIA) and in the squamous epithelium of the control tissue with the methods described and in the same way as in the cytologic preparations. Fig. 5 summarizes the median nuclear score values in the tissues according to Remmele et al (130). These values are elucidated with the example of patient no. 15 (Table IIA) in Fig. 6. Receptors RAR $\alpha$ (Ab 1), RAR $\beta$ (Ab 2), RXR $\alpha$ (Ab 3), $\mathrm{RXR} \beta(\mathrm{Ab} 4)$ and $\mathrm{RXR} \gamma(\mathrm{Ab} 5)$ were demonstrated both in squamous cell carcinoma and in squamous epithelia in the control tissues. There was no significant difference between the median score values for receptor expression on the carcinoma tissues and on the squamous epithelium in the control tissues: $\mathrm{Ab} 1: \mathrm{p}=0.252 ; \mathrm{Ab} 2: \mathrm{p}=0.956 ; \mathrm{Ab} 3: \mathrm{p}=0.831 ; \mathrm{Ab} 4$ : $\mathrm{p}=0.609, \mathrm{Ab} 5: \mathrm{p}=0.182$. In contrast, the median Ki-67 (Ab 6) and p53 scores (Ab 7) were significantly higher in the carcinoma tissues than in the squamous epithelium of the control tissues (Ki-67: $\mathrm{p}=0.028$, p53: $\mathrm{p}=0.003$ ) (Fig. 5).

Proof of inhibition by retinoid treatment in three cell lines. The growth inhibiting effect of retinoid treatment was examined in the three cell lines UM-SCC-35, UM-SCC-14C and $\mathrm{HaCaT}$ in the XTT test and in the MTT test in several separate assays shown in Fig. 7. Brief treatment ( $\sim 6$ days) with both $10^{-5}$ and $10^{-8} \mathrm{M}$ ATRA incurred growth inhibition of the cells of UM-SCC-35 as demonstrated both in the XTT test and in the distinctly lower extinction values in the MTT test. Comparison to the untreated cells reveals no significant difference (XTT: $p=0.109$, MTT: $p=0.100$ ). Growth in cells
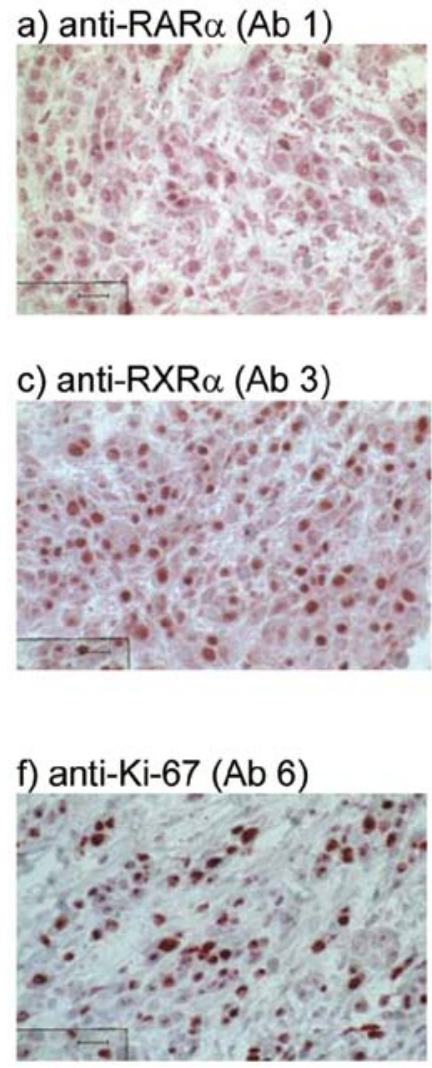
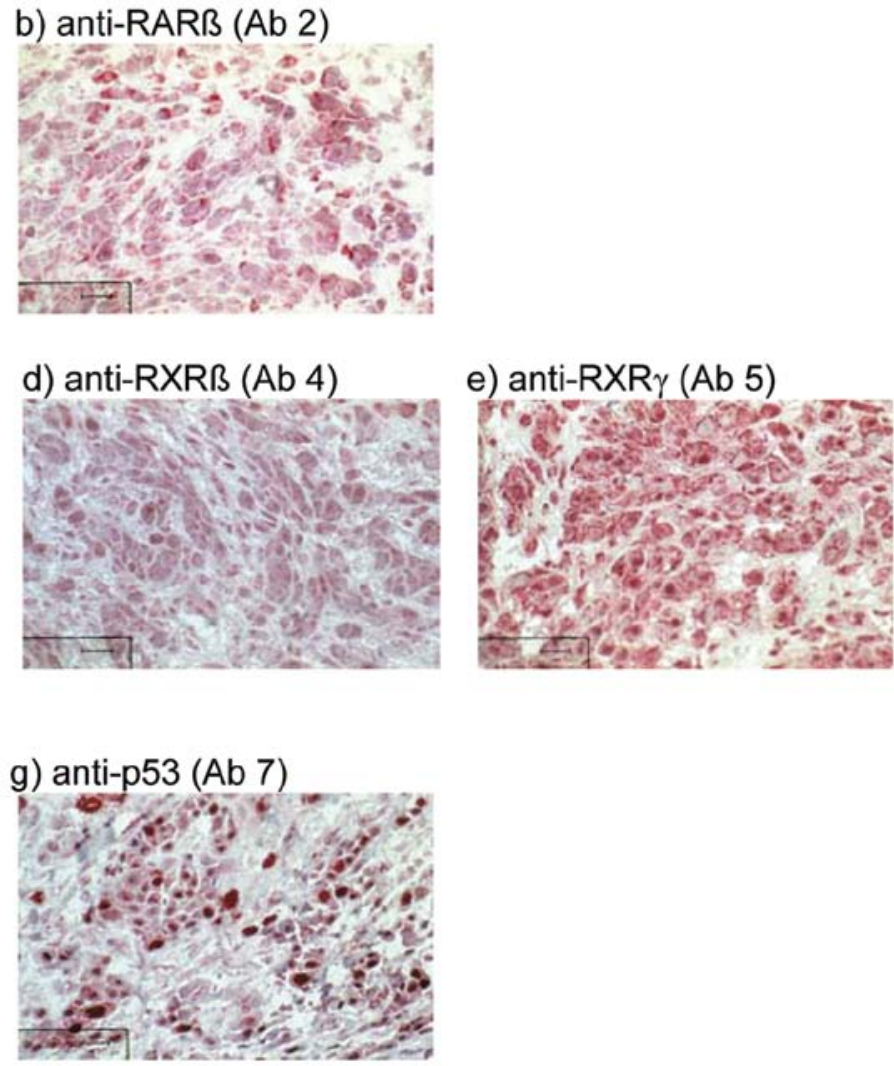


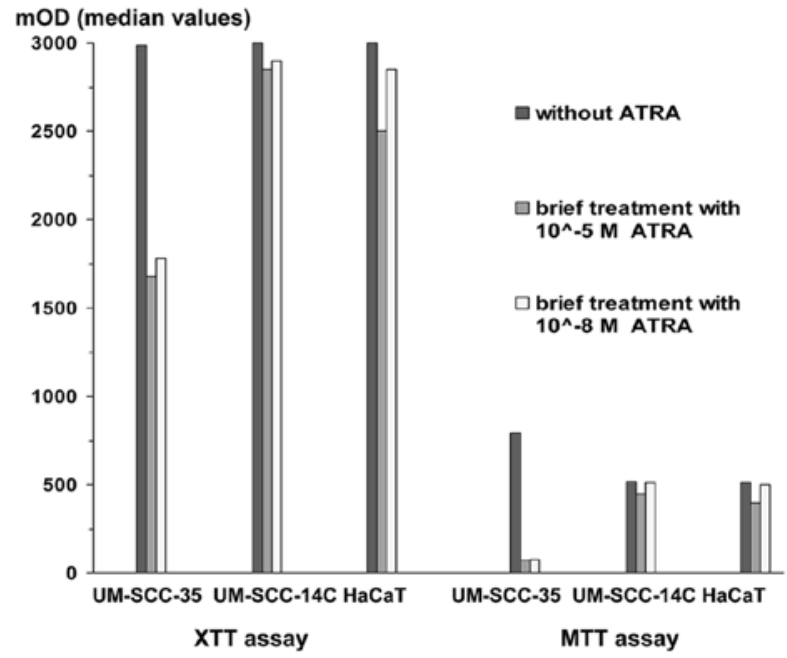

Figure 7. XTT and MTT test of the three cell lines before and after brief treatment with $10^{-5}$ or $10^{-8} \mathrm{M}$ ATRA.

of the lines UM-SCC-14 ( $\mathrm{p}=0.667)$ and HaCaT $(p=0.333)$ is inhibited only minimally or not at all by ATRA.

Proof of telomerase in cell cultures before and after retinoid treatment in the three cell lines and in tissues. In the model experiment only the UM-SCC-35 cells proved to be RA-sensitive after extended treatment with $10^{-5} \mathrm{M}$ ATRA, as evidenced in a significantly reduced telomerase activity (Fig. 8) compared to the cells without RA: without RA/brief RA p=0.686; without RA/extended RA p $<0.001$; brief RA/extended RA $\mathrm{p}=0.133$. The telomerase activity of the other cell lines did not change statistically after RA treatment $(p=0.109$ and 0.180$)$. In the tissue sections of head and neck tumors a significantly higher telomerase activity was detected than that in the control tissue from the same localization (Table II): $\mathrm{p}<0.001$.

\section{Discussion}

Given the poor prognosis for squamous cell carcinomas in the head and neck region prophylactic measures are of vital importance for these patients. Reducing the risk factors tobacco and alcohol is the most effective measure in this regard $(11,41,43,51-53)$. Numerous clinical studies have administered chemoprevention in the attempt to influence precancerous tissue changes or the postoperative course of disease. Their success is yet unclear (9-11,13-19,27-31,40-48). Most of these studies used retinoids administered in different doses and for differing periods of time. Often, however, the effects waned when the therapy was ended (49). To increase effectiveness, synthetic receptor-selective retinoids have been developed (14,28,50,57-65). Various biomarkers were applied to determine the optimal end point of chemoprophylactic treatment $(16,18,19,29,45,50,60,90,94,96-109)$.

In our model study we examined the effects of chemoprophylaxis with ATRA in cell cultures and the suitability of several biomarkers.

Growth inhibition of three cell lines by ATRA. Copper et al (123) investigated growth inhibition effected by $10^{-6}$ and $10^{-8} \mathrm{M}$

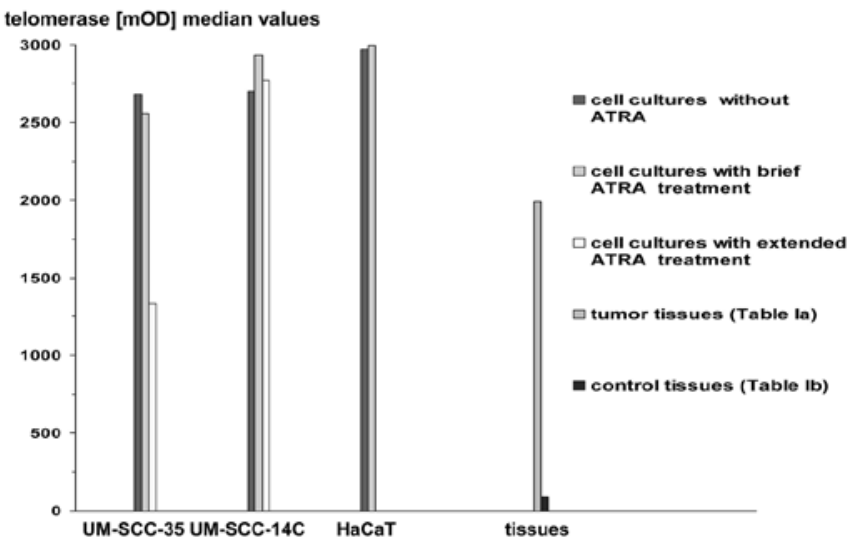

Figure 8. Telomerase activity in the three cell lines before and after treatment with $10^{-5}$ M ATRA: UM-SCC-35 and UM-SCC-14C brief ( 6 days) and extended RA ( 26 days), HaCaT only brief RA as well as telomerase activity in tissues.

ATRA on UM-SCC-11B, UM-SCC-14A, UM-SCC-14C, UM-SCC-22A, UM-SCC-22B and UM-SCC-35 (55,123). The authors (123) used a cell proliferation assay based on staining cellular protein with sulpho-rhodamine B. They determined that cells of UM-SCC-35 are most affected in their growth: a growth reduction from $100 \%$ without RA to $9.0 \pm 1.0 \%$ by $10^{-6} \mathrm{M}$ RA compared to reduction from $100 \%$ to $44 \pm 22 \%$ by $10^{-8} \mathrm{M}$ ATRA), while other cell lines such as UM -SCC-14C showed no growth inhibition by ATRA $(97 \pm 8.0 \%$ vs. $106 \pm 7.3 \%)$. The disparate behavior observed with doses up to $10^{-6} \mathrm{M}$ ATRA was confirmed in studies by Klaassen et al $(124,125)$ with the same method of proof. These authors also included a resistant cell line UM-SCC-35R which they had cultured for 8 months with increasing doses of ATRA. Le et al (134) demonstrated that ATRA inhibited growth in SCC-25 cells.

In our study we applied both the RA-sensitive cell line UM-SCC-35 and the cell line UM-SCC-14C, which is insensitive to ATRA (Fig. 7). In the XTT and MTT test we confirmed the results described by Copper et al (123) with varying growth inhibition after brief exposure ( $\sim 6$ days) to $10^{-5}$ and $10^{-8} \mathrm{M}$ ATRA. The growth inhibition that we demonstrated in UM-SCC-35 after treatment by ATRA was not significant when compared to its growth without RA. In monolayer cultures and colony counts before and after exposure to RA under an inverted microscope Jetten et al (135) confirmed our results for inhibition of proliferation of UM-SCC-35 cells in the XTT and MTT test. They also included two further cell lines, 1483 (from an untreated patient with a well-differentiated SCC T2NIM0 of the retromolar trigone) and 183 (from an untreated patient with a poorly differentiated SCC T3NOMO of the tonsil). Both these cell lines were also examined by Lotan et al (136), who in cell counts demonstrated growth inhibition after ATRA treatment. Both Jetten et al (135) and Lotan et al (136) found growth inhibition after ATRA in varying degrees and in a dose-dependent fashion. While cell line 1483 was RA-sensitive, the more aggressive cell line 183 was not inhibited in growth. Since the RA-sensitive cell line UM-SCC-35 which we used was also established after chemotherapy for a primary tonsillar carcinoma (T4N1M0, moderately well 
differentiated) and the RA-insensitive cell line UM-SCC-14C for a skin metastasis of a floor and mouth carcinoma (poorly differentiated), it may be supposed that not tumor localization but rather tumor aggressiveness relates to RA-sensitivity. This would correspond with the findings by Zou et al (137), who also demonstrated only a minimal inhibition in cells of the cell line 183 after $10^{-6} \mathrm{M}$ ATRA exposure $(19 \pm 3 \%$ growth inhibition) using electronic cell counts and calculating with the equation (1- $\left.\left.\mathrm{N}_{\text {therapy }} / \mathrm{N}_{\text {control }}\right) \times 100\right)$, while the HNSCC cell line 1483 proved to be clearly inhibited by ATRA (growth inhibition $64 \pm 7 \%$ ).

For the cell line HaCaT (121), the XTT and MTT test evidenced no growth inhibition comparable to that of UM-SCC-14C after brief exposure to $10^{-5}$ or $10^{-8} \mathrm{M}$ ATRA (Fig. 7). This result corresponds with the investigations by Schroeder and Zouboulis (128) who used a 4-methylumbelliferyl heptanoate (MUH) fluorescence assay to examine growth inhibition and with the results of Borland et al (138) who determined the number of cells before and after $10^{-6}$ to $10^{-7} \mathrm{M}$ ATRA treatment. By contrast, Jang et al (139) proved growth inhibition in HaCaT cells with up to $10^{-6} \mathrm{M}$ ATRA in the MTT test, and Wanner et al (140) with $10^{-6} \mathrm{M}$ ATRA by determining the cell counts. Chen et al (127) had investigated the impairment to growth in $\mathrm{HaCaT}$ by different retinoids in increasing concentration in the MUH fluorescence assay by up to $0.5 \times 10^{-6} \mathrm{M}$ ATRA. By contrast, the growth of HaCaT cells in our findings was particularly inhibited by ATRA.

In situ proof of $R A R$ and $R X R$ receptors and $K i-67$ and $p 53$ after brief and extended treatment of three cell lines with ATRA. Since the effects of retinoids are mediated via their nuclear RAR and RXR receptors (66-73), ATRA more effectively by the three RAR receptors (RAR $\alpha, \operatorname{RAR} \beta$ and RAR $\gamma$ ), we examined RAR (RAR $\alpha$ and RAR $\beta)$ and RXR receptors $(\mathrm{RXR} \gamma)$ on the three cell lines (Fig. 2). The results (RXR $\alpha$ and $R X R \beta$, not presented) were not statistically assessable. The only antibody against RAR $\gamma$ available to us did not yield evaluable findings.

For in situ proof of the receptors on the cell lines we chose immunocytology after pretreatment of the cytospins in the steamer. In our preliminary experiments the nuclear results had proved to be clearly better than those without pretreatment (Fig. 1). The expression of receptors $\operatorname{RAR} \alpha$ (Ab 1), RAR $\beta$ (Ab 2) and RXR $\gamma$ (Ab 5; Fig. 2) as demonstrated in immunocytology on the cells of the RA-sensitive UM-SCC-35 was low before and after brief ( $\sim 6$ days) and extended ( $\sim 26$ days) RA treatment, but not significantly reduced (Fig. 2). As opposed to this, Copper et al (123) demonstrated up-regulation of mRNA levels for RAR $\alpha$ and RAR $\gamma$ (from 12 to $24 \%$ and from 47 to $84 \%$, respectively) on the RA-sensitive cells of UM-SCC-35 during retinoid therapy, while the receptor $\mathrm{RXR} \alpha$ remained unchanged and low. In the study by Klaassen et al (124) the increase in RAR $\alpha$-mRNA was less than in the studies by Copper et al (123). Klaassen et al (124) found only very low concentrations of RAR $\beta$-mRNA in UM-SCC-35 cells, either before or after RA treatment. These in vitro findings could not be confirmed in head and neck cancer tissue samples: in these samples, RAR $\beta$ expression was higher after retinoid treatment $(18,50,60,88-90)$.

On the cells of the cell line UM-SCC-14C (Fig. 7), which was not affected by ATRA, we demonstrated RAR $\alpha$ to be significantly higher in immunocytochemistry after brief exposure to ATRA ( 6 days) (Fig. 2; Ab 1), and RXR $\gamma$ (Fig. 2; $\mathrm{Ab} 5)$, bordering on significance. This could no longer be demonstrated after extended treatment by ATRA ( 26 days). This increased expression of RAR $\alpha$ is congruent with the findings by Copper et al (123), who after treating the cells with ATRA were able to measure an increase in mRNA-RAR $\alpha$ from 94 to $100 \%$, while RAR $\gamma$ was down-regulated (mRNA from 95 to $51 \%$ ). Using the same method, Klaassen et al (124) demonstrated an even steeper increase in the expression of mRNA-RAR $\alpha$ in UM-SCC-14C after ATRA treatment. These results were congruent with ours (Ab 1; Fig. 2). However, Klaassen et al (124), contrary to our results (Fig. 2), found no mRNA of RAR $\beta$ in UM-SCC-14C cells, either before or after ATRA treatment. In other HNSCC cell lines (183, 886, 1483 and SqCC/Y1) Zou et al (137) detected an increase in expression of the RA receptors after $10^{-6}$ ATRA both in Northern blot and in immunocytology, whereby the authors did not perform quantitative evaluation of the immunocytological results.

Immunocytological examination revealed no changes in the expression of $\mathrm{Ki}-67$ ( $\mathrm{Ab} 6$; Table I) in the cells of UM-SCC-35 (Fig. 4A1-A3) or in UM-SCC-14C (Fig. 4B1-B3) after brief ( $\sim 6$ days) or extended RA treatment. There appears to be a contradiction between the obvious growth inhibition of UM-SCC-35 by ATRA (Fig. 7) and Ki-67 as a proliferation marker (141). D'Ambrosio et al (142) however demonstrated inhibition of Ki-67 by several different retinoids, including ATRA, in quantitative Ki-67-ELISA.

By choosing an antibody as proof of p53 protein (Ab 7; Table I) and pretreating the cytospins and frozen sections in the steamer we proved both the expression of wtp53 protein (wild-type of p53) and mtp53 protein (mutant form of p53) in our immunocytochemical investigations. After extended incubation with ATRA, the p53 expression in UM-SCC-35 cells was clearly reduced to borderline significance (Fig. 4A4-A6). In immunocytochemistry, Hauser et al (143) demonstrated p53 in untreated cells of UM-SCC-14C, as we also did in this cell line without and after RA treatment (Figs. 3 and 4B4). After brief and extended ATRA treatment, the p53 scores in the cells of UM-SCC-14C were demonstrated to be comparable to those previous to RA treatment (Figs. 3 and 4B4-B6). The absence of growth inhibition after brief RA incubation with $10^{-5}$ and $10^{-8}$ M ATRA (Fig. 7) is accompanied in our model study in the case of UM-SCC-14C by a non-reduction of p53 expression (Fig. 4B3-B6). In a quantitative p53 ELISA following RA treatment, D'Ambrosio et al (142) showed in 10 of 15 other HNSCC cell lines a decrease in mtp53 which was not the case in 5 of 15 cell lines. Bradford et al (144) demonstrated p53 mutations in the cell line UM-SCC-14A, established from a primary carcinoma of the floor of the mouth, in the sequence analysis of the p53 gene. In the PCR, Sun et al (61) detected p53 mutations in different HNSCC cell lines, among others in cells of UM-SCC-14B. This cell line had been established in the relapse of the same patient. This tumor then metastasized in the patient's skin, and from this metastasis was established the ATRA-resistant cell line UM-SCC-14C which we studied. We can assume that UM-SCC-14C contains p53 mutations as do UM-SCC-14A and UM-SCC-14B. Sun et al (61) also demonstrated p53 mutants in the cell line 183A, whose growth (like that of UM-SCC-14C) was not inhibited or altered after RA treatment (Fig. 7). These 
mutants were not present in the ATRA-sensitive cell line 1484. The effects of ATRA are clearly connected with the absence of p53 mutants or, conversely, with non-sensitivity in the presence of p53 mutants. This is confirmed in the results by Nakashima et al (145), who used the HNSCC cell lines Tu138 and MDA686LN with p53 mutations. Their growth was not or only barely inhibited by $10^{-8}$ and $10^{-6} \mathrm{M}$ ATRA administered in doses comparable to those used in our study, and only markedly inhibited by a dosage of $10^{-4} \mathrm{M}$ ATRA.

In our study $\mathrm{HaCaT}$ cells were found to be $\mathrm{RA}$ insensitive (Fig. 7). The expression of receptors RAR $\alpha$ (Ab 1), RAR $\beta$ (Ab 2) and RXR $\gamma$ (Ab 5) was reduced, but not significantly (Fig. 2), after brief ATRA treatment ( 6 days). After a 24-h incubation of $\mathrm{HaCaT}$ cells using all-trans-RA, Boudjelal et al (146) were able to reduce $\operatorname{RAR} \gamma$ and $\mathrm{RXR} \alpha$ receptors at the protein level by one half. This result was not demonstrated at the level of mRNA. RAR- $\beta$ was not demonstrated, even after $24 \mathrm{~h}$ stimulation of the $\mathrm{HaCaT}$ cells with RA. The expression of Ki-67 and p53 (Figs. 3 and 4C1-C6) which was demonstrated in our study did not change significantly after brief ATRA treatment. Soo Lee et al (147) were able to prove only a slight reduction in p53 in Western blot.

p53 has already been used as a biomarker in individual chemoprevention studies $(17,29,60,89,107,109,110)$. The results of our model experiments show that proof of reduced protein expression in p53 as a biomarker indicates successful retinoid treatment. D'Ambrosio et al (142) arrive at the same conclusion. This needs confirmation in further RA sensitive cell lines. In clinical studies Geyer et al (17) and Lippman et al (87) only established effectiveness of chemoprevention with retinoids when the wild-type of p53 was not yet mutated and Shin et al (89) proved in chemoprevention studies after isotretinoin therapy (13-cis-RA) that the effects of retinoids were better in patients with a low p53 expression (response rate $65 \%$ ) than in those with higher expression (response rate 27\%).

In situ proof of $R A R$ and $R X R$ receptors and of $\mathrm{Ki}-67$ and $p 53$ on carcinomas in the head and neck region and on the control tissues. Parallel to the model experiments on cell lines we demonstrated on squamous cell carcinomas (Table IIA) and on control tissues in comparable localizations (Table IIB) with the same methods of proof and the same antibodies (Table I) the RA receptors $\operatorname{RAR} \alpha(\mathrm{Ab} 1), \operatorname{RAR} \beta$ (Ab 2), RXR $\alpha$ (Ab 3), RXR $\beta$ (Ab 4) and RXR $\gamma(\mathrm{Ab} 5)$ as well as Ki-67 (Ab 6) and p53 (Ab 7) (Figs. 5 and 6). This is congruent with the results by Lotan (32), Xu et al (85), Ralhan et al (92), Oridate et al (148), Sherman and Partridge (149) as well as Wan et al (150), who demonstrated RA receptor on normal, premalignant and malignant tissues from the head and neck region using various different methods. Although we demonstrated the RA receptors in carcinoma tissue (Fig. 5) and in the cell lines (Fig. 2). Our model experiments on cell lines show that this is not reliable enough for their use as biomarkers for a successful chemoprevention with ASTRA.

Proof of telomerase as a potential biomarker. Telomerase has been investigated and demonstrated in many studies in squamous cell carcinomas of the head and neck region (among others in 112), including in our investigations (117). Activation of telomerase points to an early carcinogenesis in this location (112-117). High telomerase activity can be demonstrated in the permanent cell lines established from head and neck tumors but also in the immortalized keratinocyte cell lines $\mathrm{HaCaT}$ (139). This raises the question of whether proof of telomerase might be a suitable biomarker for the chemoprevention of precancerous lesions or postoperatively $(17,27,100-102,107)$. Fig. 8 illustrates the telomerase activity explored in our studies in several assays before and after ATRA treatment in PCR-ELISA in the RA-sensitive cell line UM-SCC-35, the RA-resistant cell line UM-SCC-14C and in the keratinocyte line $\mathrm{HaCaT}$. In addition, we examined telomerase activity in the same tumor and control tissues (Table II) that we had used for the immunohistochemical proof of the RA receptors (Fig. 8). In none of the three cell lines did brief treatment ( 6 days) of $10^{-5}$ ATRA lead to an inhibition of telomerase activity (Fig. 8), not even in the RA sensitive growth-inhibited cell line UM-SCC-35 (Fig. 7). Only after extended treatment ( $\sim 26$ days) with $10^{-5}$ ATRA could we demonstrate a distinct inhibition of telomerase activity in the cells of UM-SCC-35 (Fig. 8). No reduction in telomerase activity was to be found in the cell lines UM-SCC-14C (Fig. 8). The fact that there was no inhibition of telomerase activity in these cells is in keeping with the absence of growth inhibition after treatment with $10^{-5}$ and $10^{-8} \mathrm{M}$ ATRA (Fig. 7). Zhang et al (151) studied the effect of both $10^{-6}$ and $5 \times 10^{-6}$ M ATRA on cells of the HNSCC line Tca8113. Both cell growth and telomerase and hTERT were markedly suppressed in this line after a 9-day treatment (151).

HaCaT cells showed no significant growth inhibition in our experiments after brief RA treatment (Fig. 7). Nor was telomerase activity significantly reduced by RA treatment (Fig. 8). As opposed to our results, Jang et al (139) observed a dosis-dependent inhibition of telomerase activity in $\mathrm{HaCaT}$ cells after a 5-day treatment of $10^{-6}, 10^{-8}$ and $10^{-10} \mathrm{M}$ ATRA, which was accompanied by a parallel reduction in inhibition of proliferation as measured in an MTT cell survival assay. The investigation by You et al (152), however, yielded the finding that the telomerase activation of established normal oral keratinocytes from the gingiva was not inhibited by ATRA.

Although our model experiments on RA-sensitive cell line UM-SCC-35 show that growth inhibition can be demonstrated even after brief RA treatment (Fig. 7) and reduced telomerase activation only after extended RA treatment (Fig. 8), our results do support proof of telomerase as a biomarker for retinoid treatment. It is however necessary to corroborate proof of telomerase activation in other RA sensitive cell lines before and after retinoid treatment.

In conclusion, in our model experiments the immunocytochemical proof of p53 and the demonstration of telomerase activity in the PCR proved to be suitable for confirming the presence or absence of growth inhibition by ATRA (XTT, MTT). With all necessary precaution we conclude that both parameters are suitable biomarkers for testing the effectiveness of a chemoprevention. In clinical chemoprevention studies Geyer et al (17), Hong et al (27), Kelloff et al (62), Liebermann et al (100), Koch (101), Kelloff et al (102) and Smith and Saba (107) also drew the conclusion that the investigation of p53 and the proof of telomerase activity can be suitable biomarkers for the chemoprevention of oral carcinomas. According to the observations made by Kelloff et al (102) the proof of telomerase activity could above all be used for applying surrogate end points in chemopreventive drug development. 


\section{Acknowledgements}

The cell lines UM-SCC-35 and UM-SCC-14C were kindly made available to us by Professor Thomas E. Carey,Department of Otolaryngology Head and Neck Surgery, University of Michigan (USA) and the cell line HaCaT by Dr Norbert Fusenig, Division of Carcinogenesis and Differentiation, German Cancer Research Center, Heidelberg. We thank Mrs. Catherine Aubel for support in translation and copy editing and Mr. Franz Hafner for the microfoto scanning. The study was supported by grants from the Berliner Sparkassenstiftung für Medizin.

\section{References}

1. Slaughter D, Southwick H and Smejkal W: 'Field cancerization' in oral stratified squamous epithelium. Cancer 6: 963-968, 1953.

2. van Oijen M and Slootweg P: Oral field cancerization: carcinogen-induced independent events or micrometastatic deposits? Cancer Epidemiol Biomarkers Prev 9: 249-256, 2000.

3. Braakhuis BJ, Tabor MP, Kummer JA, Leemans CR and Brakenhoff RH: A genetic explanation of Slaughter's concept of field cancerization: evidence and clinical implications. Cancer Res 63: 1727-1730, 2003.

4. Ha PK and Califano JA: The molecular biology of mucosal field cancerization of the head and neck. Crit Rev Oral Biol Med 14: 363-369, 2003.

5. Gath H and Brakenhoff RH: Minimal residual disease in head and neck cancer. Cancer Metastasis Rev 18: 109-126, 1999.

6.Partridge M, Li SR, Pateromichelakis S, Francis R, Phillips E, Huang XH, Tesfa-Selase F and Langdon JD: Detection of minimal residual cancer to investigate why oral tumors recur despite seemingly adequate treatment. Clin Cancer Res 6: 2718-2725, 2000.

7. van Houten VM, Tabor MP, van den Brekel MW, Denkers F, Wishaupt RG, Kummer JA, Snow GB and Brakenhoff RH: Molecular assays for the diagnosis of minimal residual headand-neck cancer: methods, reliability, pitfalls, and solutions. Clin Cancer Res 6: 3803-3816, 2000.

8. Graveland AP, de Maaker M, Braakhuis BJ, de Bree R, Eerenstein SE, Bloemena E, Leemans CR and Brakenhoff RH: Molecular detection of minimal residual cancer in surgical margins of head and neck cancer patients. Cell Oncol 31: 317-328, 2009.

9. Hong WK, Lippman SM, Itri LM, Karp DD, Lee JS, Byers RM, Schantz SP, Kramer AM, Lotan R, Peters LJ, Dimery IW, Brown BW and Goepfert H: Prevention of second primary tumors with isotretinoin in squamous-cell carcinoma of the head and neck. N Engl J Med 323: 795-801, 1990.

10. Benner SE, Lippman SM and Hong WK: Prevention of second head and neck cancer. Semin Radiat Oncol 2: 206-212, 1992.

11. Bolla M, Lefur R, Ton Van J, Domenge C, Badet JM, Koskas Y and Laplanche A: Prevention of second primary tumours with etretinate in squamous cell carcinoma of the oral cavity and oropharynx. Results of a multicentric double-blind randomised study. Eur J Cancer 30: 767-772, 1994.

12. Fountzilas G: Retinoids in the management of head and neck cancer. An update. J Chemother 6: 127-138, 1994.

13. Huber MH and Hong WK: Biology and chemoprevention of head and neck cancer. Curr Probl Cancer 18: 86-140, 1994.

14. Lippman SM, Heyman RA, Kurie JM, Benner SE and Hong WK: Retinoids and chemoprevention: clinical and basic studies. J Cell Biochem 22: 1-10, 1995.

15. Lippman SM, Spitz MR, Huber MH and Hong WK: Strategies for chemoprevention study of premalignancy and second primary tumors in the head and neck. Curr Opin Oncol 7: 234-241, 1995.

16. Lotan R: Retinoids and chemoprevention of aerodigestive tract cancers. Cancer Metastasis Rev 16: 349-356, 1997.

17. GeyerC,Papadimitrakopoulou V and Hong WK: Chemoprevention in head and neck cancer: basic science and clinical application. Semin Radiat Oncol 8: 292-301, 1998.

18. Lee J, Hong W, Hittelman W, Mao L, Lotan R, Shin D, Benner S, Xu X, Lee J, Papadimitrakopoulou V, Geyer C, Perez C, Martin J, El-Naggar A and Lippman S: Predicting cancer development in oral leukoplakia: ten years of translational research. Clin Cancer Res 6: 1702-1710,2000.
19. Papadimitrakopoulou VA: Carcinogenesis of head and neck cancer and the role of chemoprevention in its reversal. Curr Opin Oncol 12: 240-245, 2000.

20. Braakhuis BJ, Brakenhoff RH and Leemans CR: Second field tumors: a new opportunity for cancer prevention? Oncologist 10: 493-500, 2005

21. Sudb $\varnothing$ J and Reith A: The evolution of predictive oncology and molecular-based therapy for oral cancer prevention. Int J Cancer 115: 339-345, 2005.

22. Braakhuis BJ, Leemans CR and Brakenhoff RH: Expanding fields of genetically altered cells in head and neck squamous carcinogenesis. Semin Cancer Biol 15: 113-120, 2005.

23. Braakhuis BJ, Bloemena E, Leemans CR and Brakenhoff RH: Molecular analysis of surgical margins in head and neck cancer: More than a marginal issue. Oral Oncol 46: 485-491, 2010.

24. Sporn MB: Approaches to prevention of epithelial cancer during the preneoplastic period. Cancer Res 36: 2699-2702, 1976.

25. Sporn MB, Dunlop NM, Newton DL and Smith JM: Prevention of chemical carcinogenesis by vitamin A and its synthetic analogs (retinoids). Fed Proc 35: 1332-1338, 1976.

26. IUPAC-IUB Joint Commission on Biochemical Nomenclature (JCBN): Nomenclature of retinoids - recommendations 1981. Eur J Biochem 129: 1-5, 1982.

27. Hong WK, Spitz MR and Lippman SM: Cancer chemoprevention in the 21st century: genetics, risk modeling, and molecular targets. J Clin Oncol 18: S9-S18, 2000.

28. Klaassen I and Braakhuis BJ: Anticancer activity and mechanism of action of retinoids in oral and pharyngeal cancer. Oral Oncol 38: 532-542, 2002

29. Tsao AS, Kim ES and Hong WK: Chemoprevention of cancer. CA Cancer J Clin 54: 150-180, 2004.

30. Toma S, Bonelli L, Sartoris A, Mira E, Antonelli A, Beatrice F, Giordano C, Benazzo M, Caroggio A, Cavalot AL, Gandolfo S, Garozzo A, Margarino G, Schenone G, Spadini N, Sirotovà Z, Zibordi F, Balzarini F, Serafini I, Miani P and Cortesina G: 13-cis retinoic acid in head and neck cancer chemoprevention: results of a randomized trial from the Italian Head and Neck Chemoprevention Study Group. Oncol Rep 11: 1297-1305, 2004.

31. Perry CF, Stevens M, Rabie I, Yarker ME, Cochrane J, Perry E, Traficante R and Coman W: Chemoprevention of head and neck cancer with retinoids: a negative result. Arch Otolaryngol Head Neck Surg 131: 198-203, 2005.

32. Lotan R: Retinoids and their receptors in modulation of differentiation, development, and prevention of head and neck cancers. Anticancer Res 16: 2415-2419, 1996.

33. Ran L, Tan W, Tan S, Zhang R, Wang W and Zeng W: Effects of ATRA, acitretin and tazarotene on growth and apoptosis of Tca8113 cells. J Huazhong Univ Sci Technolog Med Sci 25: 393-396, 2005.

34. Zhang X, Chen ZG, Khuri FR and Shin DM: Induction of cell cycle arrest and apoptosis by a combined treatment with 13-cis-retinoic acid, interferon-alpha2a, and alpha-tocopherol in squamous cell carcinoma of the head and neck. Head Neck 29: 351-361, 2007.

35. Giannini F, Maestro R, Vukosavljevic T, Pomponi F and Boiocchi M: All-trans, 13-cis and 9-cis retinoic acids induce a fully reversible growth inhibition in HNSCC cell lines: implications for in vivo retinoic acid use. Int J Cancer 70: 194-200, 1997.

36. Hayashi K, Yokozaki H, Naka K, Yasui W, Yajin K, Lotan R and Tahara E: Effect of 9-cis-retinoic acid on oral squamous cell carcinoma cell lines. Cancer Lett 151: 199-208, 2000.

37. Masuda M, Toh S, Koike K, Kuratomi Y, Suzui M, Deguchi A, Komiyama S and Weinstein I: The roles of JNK1 and Stat3 in the response of head and neck cancer cell lines to combined treatment with all-trans-retinoic acid and 5-fluorouracil. Jpn J Cancer Res 93: 329-339, 2002.

38. Xiao B, Guo J, Lou Y, Meng D, Zhao W, Zhang L, Yan C and Wang D: Inhibition of growth and increase of alkaline phosphatase activity in cultured human oral cancer cells by all-trans retinoic acid. Int J Oral Maxillofac Surg 35: 643-648, 2006.

39. Wang A, Zeng $\mathrm{R}$ and Huang H: Retinoic acid and sodium butyrate as cell cycle regulators in the treatment of oral squamous carcinoma cells. Oncol Res 17: 175-182, 2008.

40. Klass CM and Shin DM: Current status and future perspectives of chemoprevention in head and neck cancer. Curr Cancer Drug Targets 7: 623-632, 2007.

41. Wrangle JM and Khuri FR: Chemoprevention of squamous cell carcinoma of the head and neck. Curr Opin Oncol 19: 180-187, 2007. 
42. Lippman SM, Batsakis JG, Toth BB, Weber RS, Lee JJ, Martin JW, Hays GL, Goepfert $\mathrm{H}$ and Hong WK: Comparison of low-dose isotretinoin with beta carotene to prevent oral carcinogenesis. N Engl J Med 328: 15-20, 1993.

43. Khuri FR, Lee JJ, Lippman SM, Kim ES, Cooper JS, Benner SE, Winn R, Pajak TF, Williams B, Shenouda G, Hodson I, Fux K, Shin DM, Vokes EE, Feng L, Goepfert $\mathrm{H}$ and Hong WK: Randomized phase III trial of low-dose isotretinoin for prevention of second primary tumors in stage I and II head and neck cancer patients. J Natl Cancer Inst 98: 441-450, 2006.

44. Papadimitrakopoulou VA, Lee JJ, William WN Jr, Martin JW, Thomas M, Kim ES, Khuri FR, Shin DM, Feng L, Hong WK and Lippman SM: Randomized trial of 13-cis retinoic acid compared with retinyl palmitate with or without beta-carotene in oral premalignancy. J Clin Oncol 27: 599-604, 2009.

45. Lippman SM, Benner SE and Hong WK: Cancer chemoprevention. J Clin Oncol 12: 851-873, 1994.

46. Scully C: Oral precancer: preventive and medical approaches to management. Eur J Cancer B Oral Oncol 31: 16-26, 1995.

47. Freemantle SJ, Dragnev KH and Dmitrovsky E: The retinoic acid paradox in cancer chemoprevention. J Natl Cancer Inst 98: 426-427, 2006

48. Saintigny P, El-Naggar AK, Papadimitrakopoulou V, Ren $\mathrm{H}$ Fan YH, Feng L, Lee JJ, Kim ES, Hong WK, Lippman SM and Mao L: $\triangle \mathrm{Np} 63$ overexpression, alone and in combination with other biomarkers, predicts the development of oral cancer in patients with leukoplakia. Clin Cancer Res 15: 6284-6291, 2009

49. Tradati N, Grigolat IR, Calabrese L, Costa L, Giugliano G, Morelli F, Scully C, Boyle P and Chiesa F: Oral leukoplakias: to treat or not? Oral Oncol 33: 317-321, 1997.

50. Sun SY and Lotan R: Retinoids and their receptors in cancer development and chemoprevention. Crit Rev Oncol Hematol 41: $41-55,2002$.

51. van Zandwijk N, Dalesio O, Pastorino U, de Vries $\mathrm{N}$ and van Tinteren H: EUROSCAN, a randomized trial of vitamin A and $\mathrm{N}$-acetylcysteine in patients with head and neck cancer or lung cancer. For the European Organization for Research and Treatment of Cancer Head and Neck and Lung Cancer Cooperative Groups. J Natl Cancer Inst 92: 977-986, 2000.

52. Khuri FR, Kim ES, Lee JJ, Winn RJ, Benner SE, Lippman SM, Fu KK, Cooper JS, Vokes EE, Chamberlain RM, Williams B, Pajak TF, Goepfert H and Hong WK: The impact of smoking status, disease stage, and index tumor site on second primary tumor incidence and tumor recurrence in the head and neck retinoid chemoprevention trial. Cancer Epidemiol Biomarker Prev 10: 823-829, 2001

53. Do KA, Johnson MM, Doherty DA, Lee JJ, Wu XF, Dong Q, Hong WK, Khuri FR, Fu KK and Spitz MR: Second primary tumors in patients with upper aerodigestive tract cancers: joint effects of smoking and alcohol (United States). Cancer Causes Control 14: 131-138, 2003.

54. Eicher SA and Lotan R: Differential effects of retinoic acid and $\mathrm{N}$-(4-hydroxyphenyl) retinamide on head and neck squamous cell carcinoma cells. Laryngoscope 106: 1471-1475, 1996.

55. Braakhuis B, Klaassen I, van der Leede B, Cloos J, Brakenhoff R, Copper M, Teerlink T, Hendriks H, van der Saag P and Snow G: Retinoid metabolism and all-trans retinoid acid-induced growth inhibition in head and neck squamous cell carinoma cell lines. $\mathrm{Br}$ J Cancer 76: 189-197, 1997

56. Zou CP, Youssef EM,Zou CC, Carey TE and Lotan R: Differential effects of chromosome $3 p$ deletion on the expression of the putative tumor suppressor RAR beta and on retinoid resistance in human squamous carcinoma cells. Oncogene 20: 6820-6827, 2001.

57. Costa A, Formelli F, Chiesa F, Decensi A, De Palo G and Veronesi U: Prospects of chemoprevention of human cancers with the synthetic retinoid fenretinide. Cancer Res 54: S2032-S2237, 1994.

58. Chandraratna RA: Tazarotene-first of a new generation of receptor-selective retinoids. Br J Dermatol 135: 18-25, 1996.

59. Dimery IW, Hong WK, Lee JJ, Guillory-Perez C, Pham F, Fritsche HA Jr and Lippman SM: Phase I trial of alpha-tocopherol effects on 13-cis-retinoic acid toxicity. Ann Oncol 8: 85-89, 1997.

60. Schwartz JL: Biomarkers and molecular epidemiology and chemoprevention of oral carcinogenesis. Crit Rev Oral Biol Med 11: 92-122, 2000.

61. Sun SY, Yue P, Mao L, Dawson MI, Shroot B, Lamph WW, Heyman RA, Chandraratna RA, Shudo K, Hong WK and Lotan R: Identification of receptor-selective retinoids that are potent inhibitors of the growth of human head and neck squamous cell carcinoma cells. Clin Cancer Res 6: 1563-1573, 2000.
62. Kelloff GJ: Perspectives on cancer chemoprevention research and drug development. Adv Cancer Res 78: 199-334, 2000.

63. Klaholz BP, Mitschler A and Moras D: Structural basis for isotype selectivity of the human retinoic acid nuclear receptor. J Mol Biol 302: 155-170, 2000.

64. Chun KH, Pfahl M and Lotan R: Induction of apoptosis by the synthetic retinoid MX3350-1 through extrinsic and intrinsic pathways in head and neck squamous carcinoma cells. Oncogene 24: 3669-3677, 2005.

65. Brelsford $\mathrm{M}$ and Beute TC: Preventing and managing the side effects of isotretinoin. Semin Cutan Med Surg 27: 197-206, 2008.

66. Petkovich M, Brand NJ, Krust A and Chambon P: A human retinoic acid receptor which belongs to the family of nuclear receptors. Nature 330: 444-450, 1987.

67. Giguere V, Ong ES, Segui P and Evans RM: Identification of a receptor for the morphogen retinoic acid. Nature 330: 624-629, 1987.

68. Mangelsdorf DJ, Ong ES, Dyck JA and Evans RM: Nuclear receptor that identifies a novel retinoic acid response pathway. Nature 345: 224-228, 1990

69. Heyman RA, Mangelsdorf DJ, Dyck JA, Stein RB, Eichele G, Evans RM and Thaller C: 9-cis retinoic acid is a high affinity ligand for the retinoid X receptor. Cell 68: 397-406, 1992.

70. Mangelsdorf DJ, Borgmeyer U, Heyman RA, Zhou JY, Ong ES, Oro AE, Kakizuka A and Evans RM: Characterization of three RXR genes that mediate the action of 9-cis retinoic acid. Genes Dev 6: 329-344, 1992.

71. Dawson MI: Synthetic retinoids and their nuclear receptors. Curr Med Chem Anticancer Agents 4: 199-230, 2004

72. Schweitzer A, Knauer SK and Stauber RH: Nuclear receptors in head and neck cancer: current knowledge and perspectives. Int J Cancer 126: 801-809, 2010.

73. Stauber RH, Wünsch D, Knauer SK and Fetz V: An update on the pathobiological relevance of nuclear receptors for cancers of the head and neck. Histol Histopathol 25: 1093-1104, 2010.

74. Brand N, Petkovich M, Krust A, Chambon P, de Thé H, Marchio A, Tiollais P and Dejean A: Identification of a second human retinoic acid receptor. Nature 332: 850-853, 1988.

75. Mangelsdorf DJ, Ong ES, Dyck JA and Evans RM: Nuclear receptor that identifies a novel retinoic acid response pathway. Nature 345: 224-229, 1990.

76. Chambon P: A decade of molecular biology of retinoic acid receptors. FASEB J 10: 940-954, 1996.

77. Fisher GJ, Talwar HS, Xiao JH, Datta SC, Reddy AP, Gaub MP, Rochette-Egly C, Chambon P and Voorhees JJ: Immunological identification and functional quantitation of retinoic acid and retinoid X receptor proteins in human skin. J Biol Chem 269: 20629-20635, 1994.

78. Gann AA, Gates PB, Stark D and Brockes JP: Receptor isoform specificity in a cellular response to retinoic acid. Proc Biol Sci 263: 729-734, 1996.

79. Germain P, Chambon P, Eichele G, Evans RM, Lazar MA,Leid M, De Lera AR, Lotan R, Mangelsdorf DJ and Gronemeyer H: International Union of Pharmacology. LX. Retinoic acid receptors. Pharmacol Rev 58: 712-725, 2006.

80. Germain P, Chambon P, Eichele G,Evans RM, Lazar MA,Leid M, De Lera AR, Lotan R, Mangelsdorf DJ and Gronemeyer H: International Union of Pharmacology. LXIII. Retinoid X receptors. Pharmacol Rev 58: 760-772, 2006

81. Brown KS and Kane MA: Chemoprevention of squamous cell carcinoma of the oral cavity. Otolaryngol Clin North Am 39: 349-363, 2006

82. Desvergne B: RXR: from partnership to leadership in metabolic regulations. Vitam Horm 75: 1-32, 2007.

83. Barnard JH, Collings JC, Whiting A, Przyborski SA and Marder TB: Synthetic retinoids: structure-activity relationships. Chemistry 15: 11430-11442, 2009.

84. Lotan R: Suppression of squamous cell carcinoma growth and differentiation by retinoids. Cancer Res 54: S1987-S1990, 1994.

85. Xu XC, Ro JY, Lee JS, Shin DM, Hong WK and Lotan R: Differential expression of nuclear retinoid receptors in normal, premalignant, and malignant head and neck tissues. Cancer Res 54: 3580-3587, 1994.

86. Xu XC, Zile MH, Lippman SM, Lee JS, Lee JJ, Hong WK and Lotan R: Anti-retinoic acid (RA) antibody binding to human premalignant oral lesions, which occurs less frequently than binding to normal tissue, increases after 13-cis-RA treatment in vivo and is related to RA receptor beta expression. Cancer Res 55: 5507-5511, 1995 
87. Lippman SM, Shin DM, Lee JJ, Batsakis JG, Lotan R Tainsky MA, Hittelman WN and Hong WK: p53 and retinoid chemoprevention of oral carcinogenesis. Cancer Res 55: 16-19, 1995

88. Lotan R, Xu X-C, Lippman SM, Ro JY, Lee JS, Lee JJ and Hong W: Suppression of retinoic acid receptor-beta in premalignant oral lesions and its up-regulation by isotretinoin. $\mathrm{N}$ Engl $\mathrm{J}$ Med 332: 1405-1410, 1995.

89. Shin DM, Xu XC, Lippman SM, Lee JJ, Lee JS, Batsakis JG, Ro JY, Martin JW, Hittelman WN, Lotan R and Hong WK: Accumulation of $\mathrm{p} 53$ protein and retinoic acid receptor beta in retinoid chemoprevention. Clin Cancer Res 3: 875-880, 1997.

90.Papadimitrakopoulou VA and Hong WK: Biomolecular markers as intermediate end points in chemoprevention trials of upper aerodigestive tract cancer. Int J Cancer 88: 852-855, 2000.

91. Karamouzis MV, Sotiropoulou-Bonikou G, Vandoros G, Varakis I and Papavassiliou AG: Retinoid-X-receptor alpha (RXRalpha) expression during laryngeal carcinogenesis: detrimental or beneficial event? Cancer Lett 199: 175-183, 2003.

92. Ralhan R, Chakravarti N, Kaur J, Sharma C, Kumar A, Mathur M, Bahadur S, Shukla NK and Deo SV: Clinical significance of altered expression of retinoid receptors in oral precancerous and cancerous lesions: relationship with cell cycle regulators. Int J Cancer 118: 1077-1089, 2006.

93. Olasz J, Juhász A, Remenár E, Engi H, Bak M, Csuka O and Kásler M: RAR beta2 suppression in head and neck squamous cell carcinoma correlates with site, histology and age. Oncol Rep 18: 105-112, 2007.

94. Khuri F, Lippman S, Spitz M, Lotan R and Hong W: Molecular epidemiology and retinoid chemoprevention of head and neck cancer. J Natl Cancer Inst 89: 199-211, 1997.

95. Lippman SM, Sudb $\varnothing$ J and Hong WK: Oral cancer prevention and the evolution of molecular-targeted drug development. J Clin Oncol 23: 346-356, 2005.

96. Boyle P, Chiesa F and Scully C: Chemoprevention and oral cancer-(more) trials and (more) tribulations. Eur J Cancer B Oral Oncol 31: 1-2, 1995.

97. Zänker KS: Chemoprevention of cancer for the next millennium -quo vadis? Cancer Lett 143: S7-S11, 1999

98. Copper MP, Braakhuis BJM, de Vries N, van Dongen GA, Nauta JJP and Snow GB: A panel of biomarkers of carcinogenesis of the upper aerodigestive tract as potential intermediate endpoint in chemoprevention trials. Cancer 71: 825-830, 1993.

99. Kim J and Shin DM: Biomarkers of squamous cell carcinoma of the head and neck. Histol Histopathol 12: 205-218, 1997.

100. Lieberman R, Crowell JA, Hawk ET, Boone CW, Sigman CC and Kelloff GJ: Development of new cancer chemoprevention agents: role of pharmacokinetic/pharmacodynamic and intermediate endpoint biomarker monitoring. Clinical Chemistry 44 420-427, 1998.

101. Koch W: Clinical implications of biomarkers in head and neck cancer. Curr Oncol Rep 1: 129-137, 1999.

102. Kelloff GJ, Sigman CC, Johnson KM, Boone CW, Greenwald P, Crowell JA, Hawk ET and Doody LA: Perspectives on surrogate end points in the development of drugs that reduce the risk of cancer. Cancer Epidemiol Biomarkers Prev 9: 127-137, 2000.

103. Kim ES, Hong WK and Khuri FR: Chemoprevention of aerodigestive tract cancers. Annu Rev Med 53: 223-243, 2002.

104. Papadimitrakopoulou V: Chemoprevention of head and neck cancer: an update. Curr Opin Oncol 14: 318-322, 2002.

105. Wirth LJ, Haddad RI and Posner MR: Progress and perspectives in chemoprevention of head and neck cancer. Expert Rev Anticancer Ther 3: 339-355, 2003.

106. Glover KY and Papadimitrakopoulou VA: Chemoprevention of head and neck cancer. Curr Oncol Rep 5: 152-157, 2003.

107. Smith W and Saba N: Retinoids as chemoprevention for head and neck cancer: where do we go from here? Crit Rev Oncol Hematol 55: 143-152, 2005.

108. Kelloff GJ, Lippman SM, Dannenberg AJ, Sigman CC, Pearce HL, Reid BJ, Szabo E, Jordan VC, Spitz MR, Mills GB, Papadimitrakopoulou VA, Lotan R, Aggarwal BB, Bresalier RS, Kim J, Arun B, Lu KH, Thomas ME, Rhodes HE, Brewer MA Follen M, Shin DM, Parnes HL, Siegfried JM, Evans AA, Blot WJ, Chow WH, Blount PL, Maley CC, Wang KK, Lam S, Lee JJ, Dubinett SM, Engstrom PF, Meyskens FL Jr, O'Shaughnessy J, Hawk ET, Levin B, Nelson WG and Hong WK: AACR Task Force on Cancer Prevention: Progress in chemoprevention drug development: the promise of molecular biomarkers for prevention of intraepithelial neoplasia and cancer - a plan to move forward. Clin Cancer Res 12: 3661-3697, 2006.
109. Lippman SM and Hawk ET: Cancer prevention: from 1727 to milestones of the past 100 years. Cancer Res 69: 5269-5284, 2009.

110. Brennan M, Migliorati CA, Lockhart PB, Wray D, Al-Hashimi I, Axéll T, Bruce AJ, Carpenter W, Eisenberg E, Epstein JB, Holmstrup P, Jontell M, Nair R, Sasser H, Schifter M, Silverman B, Thongprasom K, Thornhill M, Warnakulasuriya S and van der Waal I: Management of oral epithelial dysplasia: a review. Oral Surg Oral Med Oral Pathol Oral Radiol Endod 103: S19.e1-S19.e12, 2007

111. Niles RM: Biomarker and animal models for assessment of retinoid efficacy in cancer chemoprevention. Acta Pharmacologica Sinica 28: 1383-1391, 2007.

112. Mao L, El-Naggar A, Fan Y-H, Lee J, Lippman S, Kayser S, Lotan R and Hong W: Telomerase activity in head and neck squamous cell carcinoma and adjacent tissues. Cancer Res 56: 5600-5604, 1996.

113. Curran A, Denis K, Irish J, Gullane P, MacMillan C and KamelReod S: Telomerase activity in oral squamous cell carcinoma. Arch Otolaryngol Head and Neck Surgery 124: 784-788, 1998.

114. Patel M, Patel D, Parekh L, Raval G, Rawal R, Bhatavdekar J, Patel B and Patel P: Evaluation of telomerase activation in head and neck cancer. Oral Oncol 35: 510-515, 1999.

115. Sumida T, Hamakawa H, Sogawa K, Sugita A, Tanioka H and Ueda N: Telomerase components as a diagnostic tool in human oral lesions. Int J Cancer 80: 1-4, 1999.

116. Dhaene K, van Marck E and Parwaresch R: Telomeres, telomerase and cancer: an up-date. Virchows Arch 437: 1-16, 2000.

117. Fabricius E-M, Gurr U and Wildner G-P: Telomerase activity levels in the surgical margin and tumour distant tissue of the squamous cell carcinoma of the head and neck. Anal Cell Pathol 24: 25-39, 2002.

118. Fabricius E-M, Kruse-Boitschenko U, Khoury R, Wildner GP, Raguse JD and Klein M: Immunohistocehmical determination of the appropiate anti-hTERT antibodies for in situ detection of telomerase activity in frozen sections of head and neck squamous cell carcinomas and tumor margin tissues. Int J Oncol 34: 1257-1279, 2009.

119. Grénman R, Carey TE, McClatchey KD, Wagner JG, PekkolaHeino K, Schwartz DR, Wolf GT, Lacivita LP, Ho L, Baker SR Krause CJ and Lichter AS: In vitro radiation resistance among cell lines established from patients with squamous cell carcinoma of the head and neck. Cancer 67: 2741-2747, 1991

120. Brenner JC, Graham MP, Kumar B, Saunders LM, Kupfer R, Lyons RH, Bradford CR and Carey TE: Genotyping of 73 UM-SCC head and neck squamous cell carcinoma cell lines. Head Neck 32: 417-426, 2010.

121. Boukamp P, Petrussevska RT, Breitkreutz D, Hornung J, Makrham A and Fusenig NE: Normal keratinization in a spontaneously immortalized aneuploid keratinocyte cell line. J Cell Biol 106: 761-771, 1988.

122. Welters M, Fichtinger-Schepman A, Baan R, Hermsen M, van der Vijgh W, Cloos $\mathrm{J}$ and Braakhuis B: Relationship between the parameters cellular differentiation, doubling time and platinum accumulation and cisplatin sensitivity in a panel of head and neck cancer cell lines. Int J Cancer 71: 410-415, 1997.

123. Copper M, Klaassen I, Brakenhoff R, Cloos J, Snow G and Braakhuis B: All-trans retinoic acid induced gene expression and growth inhibition in head and neck cancer cell lines. Oral Oncol 33: 270-274, 1997.

124. Klaassen I, Brakenhoff R, Smeets S, Snow G and Braakhuis B: Expression of retinoic acid receptor gamma correlates with retinoic acid sensitivity and metabolism in head and neck squamous cell carcinoma cell lines. Int J Cancer 92: 661-665, 2001.

125. Klaassen I, Brakenhoff R, Smeets SJ, Snow G and Braakhuis B: Metabolism and growth inhibition of four retinoids in head and neck squamous normal and malignant cells. Br J Cancer 85: 630-635, 2001.

126. Klaassen I, Brakenhoff R, Smeets S, Snow G and Braakhuis B: Enhanced turnover of all-trans-retinoic acid and increased formation of polar metabolites in head and neck squamous cell carcinoma lines compared with normal oral keratinocytes. Clin Cancer Res 7: 1017-1025, 2001.

127. Chen WC, Sass JO, Seltmann H, Nau H, Orfanos CE and Zouboulis CC: Biological effects and metabolism of 9-cis-retinoic acid and its metabolite 9,13-di-cis-retinoic acid in $\mathrm{HaCaT}$ keratinocytes in vitro: comparison with all-trans-retinoic acid. Arch Dermatol Res 292: 612-620, 2000. 
128. Schroeder $\mathrm{M}$ and Zouboulis CC: All-trans-retinoic acid and 13-cis-retinoic acid: pharmacokinetics and biological activity in different cell culture models of human keratinocytes. Horm Metab Res 39: 136-149, 2007.

129. Cordell JL, Falini B, Erber WN, Ghosh AK, Abdulaziz Z, MacDonald S, Pulford KAF, Stein G and Mason DY: Immunoenzymatic labeling of monoclonal antibodies using immune complexes of alkaline phosphatase and monoclonal anti-alkaline phosphatase (APAAP complexes). J Histochem Cytochem 32 219-229, 1984.

130. Remmele W, Hildebrand U, Hienz HA, Klein P-J, Vierbuchen M, Behnken LJ, Heicke B and Scheidt E: Comparative histological, histochemical, immunohistochemical and biochemical studies on oestrogen receptors, lectin receptors, and Barr bodies in human breast cancer. Virchows Arch (Pathol Anat) 409: 127-147, 1986.

131. Wittekind Ch, Meyer HJ und Bootz F (eds): TNM Klassifikation maligner Tumoren. UICC International Union Against Cancer. 6. Aufl. Korr. Nachdruck. Kopf- und Halstumoren (in German) $19-52,2005$.

132. Lowry OH, Rosenbrough NJ, Farr L and Randall RJ: Protein measurement with the folin phenol reagent. J Biol Chem 193: 265-275, 1951.

133. Sachs L: Angewandte Statistik-Anwendung statistischer Methoden. 11. Auflage Springer Verlag, Heidelberg (in German) pp889, 2004.

134. Le Q, Dawson MI, Soprano DR and Soprano KJ: Modulation of retinoic acid receptor function alters the growth inhibitory response of oral SCC cells to retinoids. Oncogene 19: 1457-1465, 2000.

135. Jetten AM, Kim JS, Sacks PG, Rearick JI, Lotan D, Hong WK and Lotan R: Inhibition of growth and squamous-cell differentiation markers in cultured human head and neck squamous carcinoma cells by beta-all-trans retinoic acid. Int J Cancer 45 195-202, 1990.

136. Lotan R, Sacks PG, Lotan D and Hong WK: Differential effects of retinoic acid on the in vitro growth and cell-surface glycoconjugates of 2 human head and neck squamous-cell carcinomas. Int J Cancer 40: 224-229, 1987.

137. Zou CP, Clifford JL, Xu XC, Sacks PG, Chambon P, Hong WK and Lotan R: Modulation by retinoic acid (RA) of squamous cell differentiation, cellular RA-binding proteins, and nuclear RA receptors in human head and neck squamous cell carcinoma cell lines. Cancer Res 54: 5479-5487, 1994.

138. Borland MG, Foreman JE, Girroir EE,Zolfaghari R, Sharma AK, Amin S, Gonzalez FJ, Ross AC and Peters JM: Ligand activation of peroxisome proliferator-activated receptor-beta/delta inhibits cell proliferation in human $\mathrm{HaCaT}$ keratinocytes. Mol Pharmacol 74: 1429-1442, 2008.

139. Jang HS, Oh CK, Jo JH, Kim YS and Kwon KS: Detection of telomerase activity in psoriasis lesional skin and correlation with $\mathrm{Ki}-67$ expression and suppression by retinoid acid. J Korean Med Sci 16: 623-629, 2001.

140. Wanner R, Wolff B, Glowacki F, Kolde G and Wittig B: The loss of desmosomes after retinoic acid treatment results in an apparent inhibition of $\mathrm{HaCaT}$ keratinocyte differentiation. Arch Dermatol Res 291: 346-353, 1999.
141. Gerdes J, Lemke H, Baisch H, Wacker HH, Schwab U and Stein H: Cell cycle analysis of a cell proliferation-associated human nuclear antigen defined by the monoclonal antibody Ki-67. J Immunol 133: 1710-1715, 1984

142. D'Ambrosio SM, Gibson-D’Ambrosio RE, Wani G, Casto B, Milo GE, Kelloff GJ and Steele VE: Modulation of Ki67, p53 and RARbeta expression in normal, premalignant and malignant human oral epithelial cells by chemopreventive agents. Anticancer Res 21: 3229-3235, 2001.

143. Hauser U, Balz V, Carey T, Grenman R, Van Lierop A, Scheckenbach K and Bier H: Reliable detection of p53 aberrations in squamous cell carcinomas of the head and neck requires transcript analysis of the entire coding region. Head Neck 24: 868-873, 2002.

144. Bradford CR, Zhu S, Ogawa H, Ogawa T, Ubell M, Narayan A, Johnson G, Wolf GT, Fisher SG and Carey TE: P53 mutation correlates with cisplatin sensitivity in head and neck squamous cell carcinoma lines. Head Neck 25: 654-661, 2003.

145. Nakashima T, Sun S, Lotan R, Fujiwara T, Yasumatsu R, Komiyama S and Clayman G: All-trans-retinoic acid enhances the effect of adenovirus-mediated wild-type p53 gene transfer in head and neck squamous cell carcinoma. Laryngoscope 111: 1459-1464, 2001.

146. Boudjelal M, Voorhees JJ and Fisher GJ: Retinoid signaling is attenuated by proteasome-mediated degradation of retinoid receptors in human keratinocyte HaCaT cells. Exp Cell Res 274: 130-137, 2002

147. Soo Lee Y, Jin DQ, Beak SM, Lee ES and Kim JA: Inhibition of ultraviolet-A-modulated signaling pathways by asiatic acid and ursolic acid in $\mathrm{HaCaT}$ human keratinocytes. Eur J Pharmacol 476: 173-178, 2003

148. Oridate N, Esumi N, Lotan D, Hing WK, Rochette-Egly C, Chambon $\mathrm{P}$ and Lotan R: Implication of retinoic acid receptor gamma in squamous differentiation and response to retinoic acid in head and neck SqCC/Y1 squamous carcinoma cells. Oncogene 12: 2019-2028, 1996

149. Sherman JA and Partridge M: Expression of retinoic acid receptors in normal, dysplastic and malignant oral epithelia. $\mathrm{Br}$ J Oral Maxillofac Surg 35: 260-266, 1997.

150. Wan H, Oridate N, Lotan D, Hong WK and Lotan R: Overexpression of retinoic acid receptor beta in head and neck squamous cell carcinoma cells increases their sensitivity to retinoid-induced suppression of squamous differentiation by retinoids. Cancer Res 59: 3518-3526, 1999.

151. Zhang P, Xu Q, Chen WT, Duan LQ, Zhang ZY and Zhou XJ: Synergistic down-regulation of telomerase by all-trans retinoic acid and antisense oligonucleotide in oral squamous cell carcinoma cell line (Tca8113). Oral Oncol 41: 909-1015, 2005.

152. You $Y$, Lee $G$ and Min B: Retinoic acid extends the in vitro life span of normal human oral keratinocytes by decreasing p16 (INK4A) expression and maintaining telomerase activity. Biochem Biophys Res Commun 268: 268-274, 2000. 